\title{
Dialectical Federalism: Habeas Corpus and the Court
}

\section{Robert M. Cover* and T. Alexander Aleinikoff ${ }^{\ddagger}$}

The American legal system has traditionally aspired to high principle while serving the mundane needs of controlling human behavior. Thus, we have produced a tradition, justly celebrated as among the glories of this civilization, which focuses upon a heritage of peacefully resolved conflict, of power more or less effectively harnessed, of liberty secured with but a smattering of unfortunate excesses that are invoked as cautionary tales. ${ }^{1}$ This does not mean that no revisionist version of this heritage exists nor that any such revisionism would be implausible or inaccurate. ${ }^{2}$ But there is a core of truth in the celebrated constitutional history of America. As a secular faith it is better than most.

The world of our secular faith is a world of ringing pronouncements, of dramatic confrontations between conflicting powers and conflicting principles. It is a visible, public arena in which issues are defined and resolved by well-articulated rules and structures. This highly visible heritage contrasts sharply with the Dickensian netherworld of mass criminal adjudication. ${ }^{3}$ There dispositions are arranged with minimum

- Professor of Law, Yale University.

+ J.D. 1977, Yale Law School.

The authors would like to thank Barbara Underwood for her helpful and thoughtful comments in reading an earlier draft of this article.

1. See, e.g., L. Hand, The Bill of Rights (1958); J.W. Hurst, Law and the Condtions of Freedom in the Nineteenth-Century United States (1956); C. Warren, The SUPREMe Court in United States History (1922).

2. See, e.g., C. Beard, An Economic Interpretation of the Constitution of the United States (1935 ed.); L. Friedman, A History of American LaW (1973); M. HorWitz, The Transformation of American Law, 1780-1860 (1976). Of course, many works do not fit neatly into revisionist or traditional categories. See, e.g., L. LeVY, THE ORIGINS of the Fifth Amendment (1968).

3. See generally L. Katz, L. Litwin \& R. BAMberger, Justice Is the CRIME (1972); National Legal Aid and Defender Ass'n, The Other Face of Justice (1973); President's Comm'n on law Enforcement and administration of Justice, The Challenge of Crime in A Free Society (1967); A. Rosett \& D. Cressey, Justice By Consent (1976). 
possible visibility. Coherent principle is difficult to discern. It is a world steeped in the failings of human beings and the institutions created to control them. The criminal law has always reflected the place of the furies in the temple of Justice.

The innovations of the Warren Court in the area of criminal procedure constituted the most ambitious attempt in our constitutional history to illuminate this dark underside of the law. ${ }^{*}$ The Court fearlessly or foolishly brought the celebrated ideals of the federal Constitution to bear on the day-to-day realities of urban administration of criminal justice. Our constitutional tradition has always been capable of such enunciations of high principle. However, inflicting principles upon resistant realities has proven a complex and frustrating business. While the substantive pronouncements of the Warren Court were as far-reaching in the criminal process as elsewhere, these proclamations were accompanied by an uncharacteristic remedial timidity.

This article will examine the remedial strategy of the Warren Court for its reforms in criminal procedure. It will suggest that the Court chose redundancy and indirection as its remedial strategy in order to mediate the pragmatic perspective of criminal administration and the idealistic vision of a secular faith. This strategy structured a dialogue on the future of constitutional requirements in criminal law in which state and federal courts were required both to speak and listen as equals. The Court shunned the more direct but intrusive controls of liability rules and equity, thus avoiding the social costs of building, imposing and supervising a new, "fair" structure for criminal adjudications. Concededly, the blessings of this strategy have been mixed, and much will be made of its deficiencies. Yet this article will suggest that the pursuit of alternative models for federal-state interaction in the criminal process is replete with difficulties.. The Burger Court has, in fact, produced a critique of the substantive and remedial dimensions of the Warren Court's work in criminal law. Our examination of that critique suggests the conclusion that the present Court has renewed a powerful and worthwhile idea in the dialogue on criminal justice, but that this idea will be only a euphemistic apology for existing institutions unless the Court faces up to the remedial implications of its own work.

4. See Friendly, The Bill of Rights as a Code of Criminal Procedure, 53 CaL. L. Rev. 929 (1965). See generally H. Packer, The Limits of the Criminal Sanction 149-246 (1968) (describing trend away from "crime-control" model to "due process" model of criminal justice system). 


\section{The Warren Court: Remedial Strategies and Constitutional Change}

\section{A. The Value of Equality and the Choice of Habeas Corpus}

The dominant theme of the Warren Court's innovations in constitutional law was equality. ${ }^{5}$ This theme was manifest in the Court's work in areas such as race relations and reapportionment. In the criminal procedure area, the primacy of equality is obvious in the many cases affording indigent defendants the right to state-provided equipage for effective litigation, whether those cases relied on the equal protection clause,$^{6}$ the right to counsel, ${ }^{7}$ or the due process clause. ${ }^{8}$

The value of equality is equally powerful if less explicit in cases like Miranda $v$. Arizona, ${ }^{9}$ which adopted exclusionary rules to compensate for the courts' presumed inability to otherwise penetrate and control low visibility police conduct that was believed (rightly or wrongly) to typify police relations with lower class and minority group suspects. Miranda suggested that the state was obligated to take affirmative measures to equalize the ability of defendants to assert rights; defendants had to be informed of their rights, particularly the right to assistance of counsel. There is language in the case which suggests that the cumulative effects of background circumstances should not be permitted to produce different outcomes in a criminal process. Chief Justice Warren stressed the impact of private interrogation on an "indigent Mexican defendant" who "was a seriously disturbed individual with pronounced sexual fantasies," and on "an indigent Los Angeles Negro who had dropped out of school in the sixth grade."10 Across-the-board standards of police behavior were

5. Sce A. Bickel, The Supreme Court and the IdeA of Progress 13 (1970); Kurland, The Supreme Court, 1963 Term-Foreword: "Equal in Origin and Equal in Title to the Legislative and Execulive Branches of the Government," 78 HARv. L. REv. 143 (1964).

6. E.g., Rinaldi v. Yeager, 384 U.S. 305 (1966) (requirement that unsuccessful incarcerated appellant repay cost of transcript violates equal protection clause); Douglas $v$ : California, 372 U.S. 353 (1963) (right to appointed counsel on appeal); Griffin v. Illinois, 351 U.S. 12, 19 (1956) (plurality opinion) (indigent defendants must be furnished transcript of trial for appellate review: "There can be no equal justice where the kind of trial a man gets depends on the amount of money he has.")

7. E.g., Gideon v. Wainwright, 372 U.S. 335 (1963).

8. E.g., In re Gault, 387 U.S. 1 (1967) (right to appointed counsel in juvenile delinquency proccedings).

9. 384 U.S. 436 (1966). See Deutsch, Neutrality, Legitimacy, and the Supreme Court: Some Intersections Betueen Law and Political Science, 20 SraN. L. REv. 169, 224-25 (1968).

10. 384 U.S. at 457 . 
then enunciated in order to protect the weakest actors in the criminal process. ${ }^{11}$

In implementing constitutional innovations in reapportionment and civil rights, the Warren Court was driven to a substantial expansion of federal equity power. ${ }^{12}$ Such an eruption in the chancery was not wholly unfamiliar to students of the history of the labor injunction or of equity receiverships prior to the enactment of statutory provisions for corporate reorganization. But the application of the injunction to governmental units and for the purposes of the Fourteenth Amendment required both imagination and structural elaborations distinct from, if no more intrinsically complex than, those of the past. The injunctive remedy that was grafted to Brown $v$. Board of Education $^{13}$ and Reynolds v. Sims ${ }^{14}$ was direct and coercive. It was a remedy that called for conforming behavior from the persons directly responsible for the alleged injury.$^{15}$ It threatened to use the "contempt" power as a sanction for resistance. ${ }^{16}$ The injunction also, and less visibly, provided a forum for negotiation of the terms of future conduct. Defendants were directly involved as participants in "settling" the terms of the decree. ${ }^{17}$ The equity court provided a forum for compulsory bargaining, often with rather stringent limitations upon the terms of the settlement. The "state plan," which became an in-

11. Of course, the Warren Court was not exclusively concerned with cquality. Many cases emphasized more traditional concerns of due process: accuracy of factfinding in the context of adversary proceedings, protection from inherently unreliable tribunals or prosecutorial overreaching. But the most controversial, the best elaborated, and most characteristic work of the Court for fifteen years was infused with the theme of equality.

12. See Fiss, Dombrowski, 86 YALE L.J. 1103, 1103-16 (1977). See also O. Fiss, The Civil Rights Injunction, The Addison C. Harris Memorial Lectures, Indiana University (Apr. $5,6,1976$ ) (on file with Yale Law Journal).

13. 347 U.S. 483 (1954).

14. 377 U.S. 533 (1964).

15. The Macon County, Alabama, school desegregation litigation is illustrative. In 1963, a federal district court ordered the members of the Macon County Board of Education to desegregate the Macon County schools. Lee v. Macon County Bd. of Educ., 221 F. Supp. 297 (M.D. Ala. 1963). A year later, the court enjoined a local mayor from interfering with the desegregation order. United States v. Rea, 231 F. Supp. 772 (M.D. Ala. 1964). Three years later, a three-judge court found it necessary to enjoin the Governor, the State Superintendent of Schools, and members of the State Board of Education to carry out the desegregation of Macon County and other Alabama public schools. Lee v. Macon County Bd. of Educ., 267 F. Supp. 458 (M.D. Ala.), aff'd per curiam sub nom. Wallace v. United States, 389 U.S. 215 (1967).

16. For an exhaustive description of contempt in the context of school desegregation, see United States v. Barnett, 330 F.2d 359 (5th Cir. 1963) (en banc; per curiam) (certifying to Supreme Court question whether contemnor due jury trial), certified question answered in the negative, 376 U.S. 681 (1964).

17. For an excellent case study in the context of school desegregation, see $O$. Fiss, InJunctions 415-81 (1972). This dimension of equity has been consistently slighted in the literature. 
stitutional feature in desegregation and reapportionment decrees, was the means by which compulsory bargaining took place. In this way equity became the midwife of constitutional innovation. It was assisted by the Warren Court's expansion of liability rules for constitutional torts ${ }^{1 s}$ and by its resurrection of enforcement of criminal laws protecting civil rights. ${ }^{19}$

Despite substantive thematic continuities between race relations and criminal justice, no such remedial steps followed the expansion of constitutional doctrine into the domain of state administration of the criminal law. It is remarkable that decisions as far reaching as Gideon v. Wainwright, ${ }^{20}$ In re Gault, ${ }^{21}$ Griffin v. Illinois,,2 Brady v. Maryland, ${ }^{23}$ Duncan v. Louisiana, ${ }^{24}$ Robinson v. California,${ }^{25}$ Miranda v. Arizon $a^{20}$ and Mapp v. Ohio ${ }^{2 \pi}$ would be announced with no remedial instrument whatsoever acting directly, coercively or prospectively upon the persons whose behavior was purportedly controlled. No injunction ordered that counsel be afforded felony defendants or juveniles. No "state plan" was demanded to establish an adequate system of providing counsel to meet Gideon or Gault standards. No decrees were issued against prosecutors or police to structure their behavior in future disclosure, arrest or search situations. Furthermore, civil liability rules were not developed for judges and prosecutors. Indeed, immunity doctrines were reaffirmed and perhaps enlarged. ${ }^{28}$ Finally, federal court displacement of inadequate state institutions was eschewed by very narrow construction of the civil rights removal

18. Monroe v. Pape, 365 U.S. 167 (1961).

19. United States v. Guest, 383 U.S. 745 (1966).

20. 372 U.S. 335 (1963).

21. 387 U.S. 1 (1967).

22. 351 U.S. $12(1956)$.

23. 373 U.S. 83 (1963) (prosecutor must divulge exculpatory evidence to state deCendant).

24. 391 U.S. 145 (1968) (holding Sixth Amendment right to jury trial applicable to states).

25. 370 U.S. 660 (1962) (criminal punishment cannot be imposed for status of narcotics addiction).

26. 384 U.S. 436 (1966).

27. 367 U.S. 643 (1961).

28. Pierson v. Ray, 386 U.S. 547 (1967), upheld the common law's grant of absolute immunity to judges in the context of a $\$ 1983$ action. The Burger Court extended this immunity to prosecutors in Imbler v. Pachtman, 424 U.S. 409 (1976).

Defense counsel do not enjoy similar explicit immunity; they are subject to malpractice actions. Federal liability under $\$ 1983$ for counsel malpractice, however, has been blocked by the unwillingness of circuit courts to hold that defense counsel's acts constitute "state action." See, e.g., United States $e x$ rel. Simmons v. Zibilich, 542 F.2d 259, 261 (5th Cir. 1976) (citing cases); Bines, Remedying Ineffective Representation in Criminal Cases: Departures from Habeas Corpus, 59 VA. L. REv. 927, 980-83 (1973). The unavailability of $\$ 1983$ combined with the narrow scope of most state malpractice standards produces, in effect, immunity for defense counsel. 
statute. 20 The absence of a remedy acting directly upon these personnel is startling, especially if we understand state courts and state lawenforcement officials to be the targets of this program for constitutional change.

The Warren Court's failure to develop equitable relief for criminal justice reform is evident in the very case that represents the Court's high water mark in the development of the injunction, Dombrowski $v$. Pfister. ${ }^{30}$ Although Dombrowshi contained broad rhetoric on the use of equity to avoid "chilling" of First Amendment rights, and although it stressed the importance of an effective opportunity for a federal forum, the opinion held closely to restraining doctrines of both equity and federalism. Dombrowski rehearsed the traditional maxim that equity would not lie unless there be no adequate remedy at law. And the Court stated that normally the defense of a criminal prosecution would constitute an adequate opportunity at law both for challenging unconstitutional criminal statutes and for remedying most institutional and procedural defects. ${ }^{31}$ Dombrowshi deliberately avoided confrontation with 28 U.S.C. $\$ 2283,{ }^{32}$ which prohibits federal courts from enjoining state proceedings except where expressly authorized by law. ${ }^{33}$ A finding that 42 U.S.C. $\$ 1983^{34}$ constituted such an express authorization would have greatly expanded the scope of equity in reforming state processes. ${ }^{35}$ Although the Burger Court later held $\S$ 1983 an exception, ${ }^{36}$ it compensated for this erosion of $\S 2283$ by evoking a quasi-constitutional doctrine of comity. ${ }^{37}$ While equity would, under Dombrowski, enjoin pre-indictment cases of extraordinary, egregious behavior by law enforcement officials or prosecutions implicating "special" constitutional doctrines such as First Amendment overbreadth, such situations had little relevance to the equality values dominant in the Court's criminal law reforms. The

29. See City of Greenwood v. Peacock, 384 U.S. 808 (1966) (construing 28 U.S.C. $\$ 1443$ (1970)); Georgia v. Rachel, 384 U.S. 780 (1966) (same).

30. 380 U.S. 479 (1965). See generally Fiss, Dombrowshi, supra note 12.

31. 380 U.S. at $484-85$.

32. 28 U.S.C. $\$ 2283(1970)$.

33. 380 U.S. at 484 n.2.

34. 42 U.S.C. $\$ 1983$ (1970).

35. The Warren Court's indecision did not resolve the conflict in the circuits. Compare Cooper v. Hutchinson, 184 F.2d 119 (3d Cir. 1950) with Baines v. City of Danville, 337 F.2d 579 (4th Cir. 1964), cert. denied, 381 U.S. 939 (1965).

36. Mitchum v. Foster, 407 U.S. 225 (1972).

37. The Court in Milchum qualified its holding by stating: "In so concluding [that $\$ 1983$ is an exception to $\$ 2283$, we do not question or qualify in any way the principles of equity, comity, and federalism that must restrain a federal court when asked to enjoin a state proceeding." Id. at 243 . The resort to these principles, rather than a narrow reading of $\$ 2283$, makes congressional revision less likely. 
few attempts to employ equity to reform criminal law met hostility at the circuit or district court level..$^{38}$

Equitable restraint tells only part of the story. It should be remembered that in the predominantly coordinate, nonhierarchical organization of American courts, there is little, if any, bureaucratic control or check upon the behavior of judges. That which does exist is confined largely to what we call "administration of justice" and relates to calendar matters, delay, and similar issues. "Performance" on constitutional rights is not likely to be within the scope of such administrative controls. ${ }^{39}$ Yet the Warren Court denied itself the only other viable tool for acting directly upon state judges to implement constitutional change. In Pierson $v$. Ray, ${ }^{40}$ the Court rejected a federal liability rule under $\S 1983$ by reading into that section the common law immunity standard for judges.

What the Warren Court did produce as remedial counterpart to the constitutionalization of criminal procedure was an expanded federal writ of habeas corpus. ${ }^{41}$ Fay $v$. Noia ${ }^{42}$ and Townsend $v$. Sain ${ }^{43}$ were decided on the same day as Gideon v. Wainwright ${ }^{44}$ and Douglas v. California. ${ }^{45}$ The habeas corpus that Fay and Townsend created was to be the vehicle for the reform in which Gideon and Douglas were key elements. Habeas corpus (like appellate review) is a remedy that acts not upon those persons whose behavior is the target of reform but upon institutional outcomes. Policemen are not penalized for illegal searches; judges are not fined for failures to appoint counsel, to empanel proper juries or to exclude illegal evidence. Rather, the defendant's release is held out as the incentive to redo the process until it is done correctly. ${ }^{40}$

38. See Maraist, Federal Injunclive Relief Against State Court Procedings: The Significance of Dombrowski, 48 'Tex. L. Rev. 535, 580 (1970) (citing cases).

39. The American model is by no neans the only possible onc. Professor Mirjan Damaska has provocatively suggested that the familiar adversarial-inquisitorial dichotomy cliaracterizing the Anglo-.Imerican and Continental criminal justice systems respectively be replaced by a paracligmatic dichotomy between coordinate and hicrarchical structures of authority. The absence of bureaucratic accountability in the American system must be seen as part of a gencral lack of performance accountability by judges. Immunity from tort liability, absence of equity as a remedy for defects, and primitive or nonexistent bureaucratic techniques all contribute to this deficiency. See Damaska, Structures of Authority and Comparalive Criminal Procedure, 84 YaLE L.J. 480 (1975).

40. 386 U.S. $547,553.54$ (1967).

41. See McFeely, Habeas Corpus and Due Process: From Warren to Burger, 28 BaYLoR L. Rcv. 533, $537-40$ (1976).

12. 372 U.S. 391 (1963).

43. 372 U.S. 293 (1963).

44. 372 U.S. 335 (1963)

45. 372 U.S. 353 (1963).

46. Reversal of convictions constitutes a somewhat roundabout way of affecting behavior of actors in the criminal process. This is most obvious and most discussed with 
The Court's expansion of habeas corpus ensured the active participation of federal courts in the protection and definition of constitutional rights. Justice Brennan made clear this underlying premise of Fay by recognizing "the manifest federal policy that federal constitutional rights of personal liberty shall not be denied without the fullest opportunity for plenary federal judicial review." 47 This "manifest policy," favoring independent federal adjudications free from the impact of structural deficiencies in state criminal processes, employed redundancy as a safeguard. If two overlapping or redundant processes are to serve as a check on one another, they must be independent in the sense that malfunction of one does not affect the functioning of the other. Fay guaranteed such broad independent review in three ways. First, it reaffirmed the doctrine of Brown $v$. Allen that state court adjudications could not estop federal court adjudication. ${ }^{48}$ Second, it held that defendants could not lose their opportunity to raise federal claims in federal court unless they had "deliberately bypassed" state procedures for adjudicating such claims. ${ }^{* 0}$ This high waiver standard ${ }^{50}$ was reinforced by a third principle: waiver depended upon "the considered choice" of the defendant; the acts of counsel would not automatically bind the client. ${ }^{51}$

Fay certainly increased the number of claims brought in federal court, but it did so in a way that avoided difficult questions concerning the relation of counsel to client and the standards for judicial behavior. Rather than determining whether counsel's behavior was such

respect to police behavior and the exclusionary rules goreming illegally obtained evidence. See generally Oaks, Studying the Exclusionary Rule in Scarch and Seizure, 37 U. CHI. L. Rev. $665,736-57$ (1970). Yet reversing convictions to elicit conforming behavior from judges, prosecutors and defense counsel may be equally problematic. Where the behavior of these actors is based upon a desire to obtain convictions, blocking institutional outcomes appears to be a rational strategy. However, the effectireness of the strategy is open to question when only a small number of such cases actually reach the federal courts. Morcorer, a great deal of the behavior which may be a target of constitutional reform does not arise through pursuit of illegitimate institutional objectives, but rather though mistake or pursuit of self-interest within burcaucratic and political configurations. Releasing prisoners for constitutional error in arrest or at trial may produce reform among conscientious judges or policemen or among individuals who wish to please those in charge of promotions. But it is less likely to be effective if the institution itsclf induces the target behavior or if there is no accountability mechanism which makes such results count against the self-interest of the actor (e.g., if a reversal for ineffective assistance does not hurt the ability of the lawyer to attract clients).

47. 372 U.S. at 424.

48. Id. at 422 (quoting Brown v. Allen, 344 U.S. 443, 478 (1953)).

49. 372 U.S. at $438,439-40$.

50. For purposes of this article, the phrase "high waiver standard" will refer to a requirement that the court only find a waiver after it is convinced that the defendant's failure to raise a claim was knowing and voluntary. It is a standard which makes it relatively difficult to infer a waiver.

51. 372 U.S. at 439 . 
that it was fair to attribute his acts to his client, a federal court would rule on the underlying right at issue unless the defendant himself had bypassed state adjudication. Similarly, federal courts avoided potentially insulting inquiries into the reasons for the failure of the trial judge to raise and correct errors not called to his attention by the defense. The Fay waiver rule ensured that the deficiencies of counsel and forum in the state proceeding could not, by inadvertance or design, create a situation in which the federal right had to be forgone in the federal court as well. Townsend $v$. Sain secured similar independence of the federal forum from state factfinding processes. ${ }^{52}$

The choice of the indirect remedy of habeas corpus, however, sacrificed some of the momentum for reform of state criminal justice. While Fay and Townsend secured the federal tribunal's independence from the state courts and superiority in the sense of the independent power to block state institutional outcomes in a particular case, those cases did not and could not secure the power to impose upon the state courts the main elements of the Warren Court's program. The relief afforded by habeas corpus is almost always extended only to a single petitioner, ${ }^{53}$ and the form of relief is limited to release from confinement. ${ }^{54}$ Thus, habeas corpus was not always the most appropriate remedy for furthering the Warren Court's goal of equality. The rules of Mapp v. Ohio ${ }^{55}$ and Miranda, for example, as enforced through broad habeas, were likely to be less effective in protecting disadvantaged groups from illegal police practices than a remedy akin to

52. Townsend $v$. Sain lield that federal courts, upon a petition for a writ of habeas corpus, mtst hold an evidentiary hearing to determine a constitutional claim if the petitioner "did not receive a full and fair evidentiary hearing in a state court." 372 U.S. at 312. The Court listed six particular situations in which a hearing would be mandatory:

If (l) the merits of the factual dispute vere not resolved in the state hearing; (2)

the state factual determination is not fairly supported by the record as a whole; (3)

the fact-finding procedure employed by the state court was not adequate to afford a

full and fair hearing; (4) there is a substantial allegation of newly discovered evidence; (5) the material facts were not adequately developed at the state-court hearing; or (6) for any reason it appears that the state trier of fact did not afford the habeas applicant $a$ full and fair fact hearing. Id. at 313.

53. But see United States ex rel. Sero v. Preiser, 506 F.2d 1115 (2d Cir. 1974), cert. denied, 421 U.S. 921 (1975) (granting class relief in habeas corpus under authority of the All Writ Statute, 28 U.S.C. \$ 1651 (1970)).

54. Since a successful petition for a writ of habeas corpus results only in discharge of the petitioner, the potential of federal habeas corpus to impose direct structural reform of state institutions is slight. Of course, the threat of release could induce structural change, and the remedy of release could be conditioned upon the state's failure to act in some designated fashion. However, the state always retains the option of ignoring the threat and suffering the consequences of a prisoner's discharge.

55. 367 U.S. 643 (1961) (extending Fourth Amendment exclusionary rule to states). 
the civil rights injunction. ${ }^{j 6}$ As we shall see below, state courts retained the power legitimately to resist lower federal court determinations of what the Constitution required of the state criminal courts. Such resistance would be purchased at the price of some released petitioners and many retrials, but a state court willing to pay such a price remained in a relatively independent position under Fay.

A strategy of redundancy, although limited by these factors, had correlative advantages. First, the Court avoided the Russian Winter of direct enforcement of an unpopular constitutional innovation. By 1963 the Court had faced massive resistance to Brown v. Board of Education through much of the South, and was aware how difficult the remedial process could become. Second, habeas corpus and the redundancy it afforded seemed to meet the principal needs and demands of those most directly affected by constitutional deficiencies in the criminal process: defendants and prisoners wanted reversals of convictions and release, not institutional reform. Appellate review and habeas corpus were the traditional and natural remedies. ${ }^{57}$

Fay's strategy of redundancy also had a significant impact on the creation and reliability of protection of constitutional rights. Reliability of protection was, in fact, a major reason for the Warren Court's choice of habeas corpus: it increased the probability that constitutional rights would not be wrongfully denied. The impact upon the creation of rights was perhaps an unforeseen but potentially more profound development. Fay permitted and encouraged a dialogue between state and federal courts that helped define and evolve constitutional rights.

56. The relative inefficacy of habeas corpus relict is due to two factors: the small number of state convictions that are successfully challenged in federal cout, sec Shapiro, Federal Habeas Corpus: A Sutly in Massachusclls, 87 H skv. L. Rlx. 321, 333-35 (1973), and the likelihood of a low correlation between frustration of outcomes (resersal of convictions) and altered "front-line" police behavior, see note 46 supra. lor a vivid contrast of the reach of the remedies, compare the right to treatment cases using habcas corpus, e.g., Lake v. Cameron, 331 F.2d 771 (D.C. Cir. 1964), cert. denied, 382 U.S. 863 (1965) (orclering district court hearing on Iegality of petitioner's commitment to mental hospital), with those cmploying injunctive relief, e.g., Wyatt $r$ Sticknev, 344 F. Supp. 387 (M.D. Ala. 1972), aff'd in part, remanded in parl, and reserved in part sub nom. Wyatt v. Aderholt, 503 F.gd 1305 (5th Cir. 1974).

The injunction has occasionally been used to control particularly egregious police bchavior. E.g., Lankford v. Gelston, 36t F.2d 197 ( 4 th Cir. 1966) (en banc). But sce Rizzo v. Goodc, 423 U.S. 362 (1976). Commentators have suggested a third method of controlling police misconduct: promulgation and enforcement by police departments of rules of police conduct. See Amsterdam, Perspectives on the Fourth Amendment, 58 Mins. L. Rev. 349, 416-39 (1974); McGowan, Rule-Making and the Police, 70 Mcu. L. REv. 659 (1972).

57. Habeas corpus might also be favored over equitable relief on technical grounds: it provides an adequate remedy at law for alleged deprivations of constitutional rights in a state proceeding. 


\section{B. Redundancy and Constitutional Rights}

\section{Reliability}

Defenders of a broad habeas corpus jurisdiction have often pointed to the special competence and zeal that federal judges possess in protection of federal constitutional rights. ${ }^{58}$ Their concern is nurtured by institutional factors. As Professor Abraham Sofaer argued long ago in a brilliant student note, the habeas corpus proceeding as contemplated by Fay encourages successful vindication of federal rights by isolating them from other elements in the criminal process and making them the special concern of a special forum. ${ }^{59}$

But even without the special awareness and position of federal judges, redundancy fosters greater certainty that constitutional rights will not be erroneously denied. A simple exercise will establish that the probability of two independent courts both acquiescing in upholding a conviction with a given constitutional error is the product of the respective probabilities of error of the two courts. If each court has a probability of this sort of error of .1 , then the probability of such an error surviving the double scrutiny, given a unanimity decision rule, is .01-a measureable gain in certainty. This rise in certainty that a conviction will not stand where there has been an erroneous adjudication of a constitutional right, however, entails a corresponding increase in the probability that there will be an erroneous failure to convict. That is, the probability that one of two courts will make an erroneous recognition of a constitutional right is greater than the probability that one court acting alone will do so."10 Redundancy-as limited to reconsideration of defendants' claims

58. Sec Wright \& Sofacr, Federal Habcas Corpus for Slate Prisoners: The Allocation of Fact-Finding Responsibility, 75 Y.xLF. L.J. 895, 898 n.14 (1966) (quoting Bator, Finality in Criminal Law and Federal Habeas Corpus for Stalc Prisoners, 76 H.nrv. L. Rev. 441, $510(1963))$.

50. Note, Federal Habcas Corpus for Slale Prisoners: The Isolation Principle, 39 X.Y.U. L. Rr. 78 (1964). See Developments in the Law-Federal Habeas Corpus, 83 Hakv. I. RLv. 1038, $1057(1970)$ [hereafter cited as Developmenls]. That this special concern has often characterized the federal bench is conceded in Stonc v. Powell, 428 U.S. 465, .193 11.35 (1976).

60. We will assume that the two courts act independently of one another. While this assumption is not cntircly accurate it is fair to say that $I^{*}$ ay $v$. Noia and Townsend $v$. Sain were designed to approximate such independence. Assume that the probability of a correct eletermination is the same for each court. Assume further that the courts have the same probability for correct acepuittal as for correct convictions, i.e., .9. If the defendant is in fact guilty, the probability of the state court correctly convicting is .9. As to those prisoners who scek habeas corpus relicf, the probability of correct denial of relief by the federal court is again .9. The probability of both courts independently reaching correct conclusions of guilt is the product of the probabilities of the two independent crents: $(.9 \times .9)$ or .81 . The probability of nonconviction error has thus been increased from .1 to .19. The increase from .l (probability of erroncous acquittal by 
of error-therefore establishes a biased decision rule against convictions with erroneous adjudications of constitutional rights. Some would argue against such a rule. But the mandate of $F a y$ was clear: it was the deprivation of constitutional rights that was to be avoided. " "The State court cannot have the last say when it, though on fair consideration and what procedurally may be deemed fairness, may have misconceived a federal constitutional right." "\#61

Redundancy could also spark a reduction of constitutional errors on the part of the states. If state courts knew that errors would be corrected by a federal court requiring a retrial, they might be more solicitous toward claims brought before them. Moreover, as Justice Brennan has argued in cases and articles, the existence and exercise of federal habeas corpus jurisdiction may stimulate the states to develop and improve procedures for the adjudication and protection of constitutional rights. ${ }^{62}$

\section{Dialectical Federalism}

The biased decision rule of Fay in favor of nonerroneous adjudications of constitutional rights was no doubt intended by the Court.

state court) has occurred because the erroneous acquittal of the state court is not affected by the redundancy of habeas corpus and thus must be added to the probability of erroneous federal issuance of the writ after correct judgment of conviction by the state court $(.9 \times .1=.09)$. Thus $.1+.09=.19$.

Actually, the increase in acquittal biased errors is not nearly this large. The .09 rate of error increase must be diminished by whaterer percentage of cases are retried with correct judgments of conviction. The actual rate of retrial and reconviction is of coursc a purely empirical question. Similarly, the error rate assumptions here are only illustrative. We-obviously have no data remotely approaching the necessary quality to make "error" rate judgments about particular state and federal courts. More significantly, we have no fully adequate criteria about what should count as a defendant who is "in fact guilty" nor about what constitutes a relcvant error. Nevertheless, the direction of change induced by redundancy is clear. If a third layer of redundancy were added we would reduce the probability of erroneous convictions to $.1 \times .1 \times .1=.001$. The probability of correct convictions would be decreased, $.9 \times .9 \times .9=.729$, while the probability of erroneous nonconviction [assuming no retrials] would be increased, $.1+(.9 \times$ $.1)+(.81 \times .1)=.271$. The area of erroneous nonconviction is the area in which two or more courts disagree. While the disagreement of the tribunals tells us nothing about which court is correct, it docs identify a subset of the total number of cases in which nearly all trial errors will be found (subject to the low probability of all courts making the same error in a particular case).

61. 372 U.S. at 422 (quoting Frankfurter's opinion in Brown v. Allen, 344 U.S. 443, $508(1953))$.

62. Henry v. Mississippi, 379 U.S. 445,453 (1965); Brennan, Federal Habeas Corpus and State Prisoners: An Exercise in lederalism, 7 UTAH L. REv. 423, 442 (1961). This view is also sharcd by Professor Reitz. See Reitz, Federal Habeas Corpus: Impact of an Alortive State Proceeding, if H.1Rv. L. REv. 1315, 1352-54 (1961). For counterarguments to those presented here, sec pp. 1072-78 infra.

Other bencfits of broad habeas are imaginable. Shapiro's significant study in the District of Massachusetts indicates that substantial federal-state communication may occur on an informal level, sparked by a habeas petition. Shapiro, supra note 56, at $339-42$. 
But the Court was probably less conscious that the choice of habeas corpus also was consistent with a special model of federalism and the establishment of a unique dynamics, a dialectic between state and federal courts. This dialectic is an important yet unrecognized device for translating those values which the Court has identified as significant into specific constitutional rights.

\section{a. Rights and Remedial Strategies}

Discussions of the appropriate role of federal law in altering state institutions often proceed little beyond the staking out of initial positions. Two paradigms are developed and defended: a model of hierarchical imposition of federally determined values; and a model of fragmentation, justifying value choices by the states. Political and prudential factors may be conceded as qualifications of either pure model, but we have no affirmative image of a middle ground.

The classic paradigm of hierarchical imposition entails: (a) federal (Supreme Court) articulation of a value; (b) federal court definition of the rights which flow from that value; and (c) direct and coercive federal court imposition of the rights on state personnel and institutions. ${ }^{63}$ Under this model, states are left little or no room to influence the choice or shape of developing rights. Alternatively, the fragmentation model posits fifty-one social laboratories, each freely pursuing its own definition of values. States retain the major role in evolving rights subject only to some vague limits on arbitrariness and irrationality. ${ }^{64}$ The theory does not specify a method by which one laboratory's results are chosen over another's.

Both paradigms create a sense that conflict and indeterminancy are dysfunctional. At the hierarchical end of the spectrum such conflict is called resistance or interposition and is a violation of Article VI. At the fragmentation end, it is called federal interference with states' rights. Under both theories one system has exclusive or preeminent

63. The classic cxample, of course, is the history of school desegregation. See pp. 1038-39 supra.

64. This role for the states can be fostered by at least two Supreme Court strategics. The Court may deciele that the Constitution simply does not speak on a particular issue. For example, it can hold that the Constitution creates no protected interest in reputation, and that, therefore, the states may choose to protect the interest as they see fit. See Paul v. Davis, 424 U.S. 693 (1976). Or, the Court may find a constitutional right implicated by certain state actions but decide that the states are to be trusted to implement constitutional requirements. Thus, while the Court has held that a child has a constitutionally protected interest in freedom from restraint and physical punishment at the hands of school officials, it has ruled that state common law remedies are presumptively capable of protecting that interest. See Ingraham v. Wright, 97 S. Ct. 1401, 1413-18 (1977); id. at 1427-28 (Sterens, J., dissenting). 
voice as to the value to be chosen or imposed. Such a political model suffers from the lawyer's disease of sovereignty.

A third model of federal-state interaction is possible, premised upon conflict and indeterminancy. Values become rights when lawyers fight about their implications. This model obtains whenever jurisdictional rules link state and federal tribunals and create areas of overlap in which neither system can claim total sovereignty. Conflicts will arise where values identified by the Supreme Court are interpreted differently by the two court systems. Where the Supreme Court refuses to impose a solution, an open-ended dialogue can ensue. The "dialectical federalism" that emerges becomes the driving force for the articulation of rights. ${ }^{6 j}$

A federal-state dialogue can proceed with varying levels of attentiveness, depending on the linkage of the two systems. For example, in situations of concurrent jurisdiction, a competition for judicial business may exist. This may lead to the elaboration of legal doctrine, as courts vie for prestige or influence with an eye to the other system's developments. ${ }^{66}$ The dialogue becomes most intense when state and federal court systems both have input into the resolution of a single dispute. Thus, the availability of Supreme Court review of state court adjudications of federal claims has an impact on state decisions. Similarly, state adjudications affect federal decisions through the abstention doctrine. ${ }^{67}$

Perhaps the most dramatic example of dual input is habeas corpus. Given the unanimity rule for a valid conviction, the habeas relationship demands mutual respect and awareness. Habeas corpus has often

65. Alexander Bickel recognized a different sort of dialogue that permitted clarification of values and rights. For Bickel, the institutional characteristics of the Supreme Court fostered and often required a dialogue with political branches. His "mediating devices" grew from the Court's institutional needs.

Over time, as a problem is lived with, the Court does not work in isolation to divine the answer that is right. It has the means to elicit partial answers and reactions from the other institutions, and to try tentative answers itself.

A. Bickel, The Leist DaNgerous Branch 240 (1962). The passive virtucs that Bickel described and justified were devices for facilitating the conversation between courts and political actors.

66. In pre-Erie $v$. Tompkins days, this sort of compctition could occur in ciril matters through federal diversity jurisdiction. M. Hokwrz, supra note 2, at 220-26, notes onc example: in the 19th century federal and state courts "competed" on the attributes of negotiability. The establishment of a federal commercial law esentually orerrode state decisional rules.

67. The abstention doctrinc, deriving from Railroad Comm'n s. Pullman Co., 312 L.S. 496 (1941), holds that federal courts should refuse to render a judgment on the constitutionality of a state statute if state court construction of the statutc could obviate the need for a federal determination. See generally Field, Abstention in Constitutional Cases: The Scope of the Pullman Abstention Doctrine, 122 U. P... J. Rev. 1071 (1974). 
served to dramatize conflicting values. In the pre-Civil War era, habeas corpus served as a crucible for the abolitionist-pro-slavery debate. ${ }^{.5}$ Similarly, federal habeas corpus has functioned throughout our history as a mechanism for arguing over notions of fundamental fairness. ${ }^{99}$ But it is Brown v. Allen, Fay v. Noia and Townsend v. Sain that openly embrace a dialectical approach to programmatic reform of the criminal process. These cases, by ensuring broader overlap of state and federal court determinations, engage these tribunals in an exploration of constitutional principles. For such jurisdictional ties to produce a dialogue requires satisfaction of two preconditions: that there be no foreordained answers to the relevant questions, and that there be two distinct voices.

Thus, the dialogue occurs only where the Supreme Court has not spoken with specificity. There exists an obligation on the part of the lower court judges not only to obey a writ of the Supreme Court when it runs to them, but to defer to the words of the Court when those words apply to the case before them. If Cohens $v$. Virginia ${ }^{70}$ decided the first point firmly and forever, the second was as firmly announced in Cooper v. Aaron. ${ }^{71}$ Cooper v. Aaron, which reads into every official's oath of office an obligation to obey in good faith the constitutional doctrine of the Supreme Court, means that once the Supreme Court has spoken, it has exhausted the space for constitutional colloquy. But where the Court has not spoken, or has spoken so broadly that its statements do not answer particular questions, there is much room for federal-state dialogue. Competing principles and policies may be presented to a host of different tribunals each of which is independently capable of reaching a solution. Until Cooper $v$. Aaron comes into play, judges may act, in good faith, according to their preferred constitutional theory without risk of violating their obligations under Article VI. And state and federal judges act on a level of constitutional equality: the constitutional decisions of inferior federal courts are not binding on state courts; Cooper v. Aaron applies only to the high Court's pronouncements.

The absence of, or lacunae between, Supreme Court opinions, then,

68. See R. Covtr, Jesticr: Accesed 16t-91 (1975); Oaks, Habeas Corpius in the States1776-1565, 32 U. Cinf. L. Riv. 243, 267-70, 276-79, 283-87 (1965). This “discussion" ended with Ableman v. Booth, 62 U.S. (21 How.) 506 (1858), which held that a W'isconsin statc court could not frec a federal prisoner (a captured fugitive slave) on a writ of habeas corpus.

69. Compare Frank v. Mangum, 237 U.S. 309 (1915) with Moore v. Dempsey, 261 U.S. 86 (1923).

70. 19 U.S. (6 Wheat.) 261 (1821).

71. 358 U.S. 1 (1958). 
permits state and federal courts to speak from their own perspectives. A dialogue is created when the two systems in fact represent different viewpoints. This has generally been the case with the criminal law, where federal and state courts have tended to adopt divergent positions. We shall call these two positions "utopian" and "pragmatic" constitutionalism, respectively. ${ }^{22}$

These two opposing tendencies have been apparent throughout our constitutional history. The utopian approach to adjudication reads a more or less comprehensive order of fair and limited government into the Constitution, usually focusing on the Bill of Rights or some provision of the Fourteenth Amendment. This approach can claim such diverse adherents as Samuel Chase, ${ }^{73}$ Stephen Field, ${ }^{74}$ and William Douglas. ${ }^{75}$ The opposing "pragmatic" tendency has read into the document only ad hoc, though important, strictures upon egregious behavior by presumptively legitimate, historically validated structures of authority. Thus constitutional principle defines a perimeter; within that perimeter administrative, managerial, and efficiency concerns can hold sway. This view has claimed an equally large group of adherents, including Oliver Wendell Holmes, Jr., ${ }^{76}$ Felix Frankfurter, ${ }^{77}$ and Alexander Bickel. ${ }^{78}$

The different institutional roles that state and federal courts play make it likely that within each court system one tendency will dominate. State courts are likely to hold up the pragmatic end of the

72. Alexander Bickel has noted two similar traditions in western political thought. He labels them "Contractarian" (liberal) and "Whig" (conservative). See A. Bickel, ThE MORAlity of Consent 1-11 (1975). The utopian/pragmatic distinction is also analogous to the due process and crime control models developed by Professor Packer. See H. PAcker, supra note 4, at 149-246. Our dichotomy differs from that of the late Professor Packer in that Packer described a choice between values, whereas we are describing a choice between the possible relationships of values to reality.

73. See Calder r. Bull, 3 U.S. (3 Dall.) 386, 386-95 (1798) (Chase, J.).

74. See Slaughter-House Cases, 83 U.S. (16 Wall.) 36, 83-111 (Field, J., dissenting).

75. See, e.g., WYman v. James, 400 U.S. 309, 326-35 (1971) (Douglas, J., dissenting).

76. See, e.g., Lochner :. New York, 198 U.S. 45, 7t-76 (1905) (Holmes, J., dissenting).

77. Baker v. Carr, 369 U.S. 186, 266-330 (1962) (Frankfurter, J., dissenting).

78. See A. Bickel, supra note 72, at 26-30.

Constitutional law scholarship in the 1950s and 1960s advanced beyond the achicvements of earlier decades primarily by explicating the dialectic between these opposing tendencies, rather than defending one or another approach. Thus, the scminal work of Charles Black and Alexander Bickel demonstrated that the lendencies in constitutional thought can never be unalloyed pure elements in practice. See . . B1CKEI, supra note 65; C. BLiCK, The People and The Court (1960). A Court bent upon validating current behavior soon loses the force of its legitimating mission by abstaining entirely from utopian perspectives upon an imperfect world. Conversely, a Court bent upon wholesalc utopian reform soon finds the political capital necessary to effectuate change squandered, for it ignores the historical base from which change must proceed and the presumptive claim that this base has to legitimacy under the Constitution. 
dialogue about our system of mass criminal justice. State courts are employed at the firing line. They have a major role in determining which cases will be processed, how many will be processed at what rate of speed, what resources will be expended on these cases, by what procedures cases will be decided, and, of course, what the decision will be. These tasks entail coordination of independent or quasi-independent elements in the criminal justice system-prosecutors, defense counsel, prison and probation officials, police. They also involve sizeable managerial problems with respect to the courts themselves and their own personnel. Finally, they involve the difficulties of decisions about guilt, innocence, and disposition. The constraints of "constitutional rights" permeate the ways in which these tasks may permissibly be carried out. Clearly, the simultaneous pursuit of so many objectives is facilitated if constraints, which hinder efficient assembly-line processes, are eliminated or read loosely. In short, given the quite difficult and legitimate objectives of the state court systems, one would hardly expect them to have a utopian perspective on constitutional rights relevant to the criminal process. ${ }^{79}$

To a large extent, the utopian perspective has characterized the efforts of lower federal courts. Because of the definition of their jurisdiction, these courts play a significant role in the creation of a constitutional common law of criminal procedure. Since they can overturn state convictions only on constitutional grounds, they necessarily speak the language of constitutional imperatives. Thus the expansion of federal habeas after Fay $v$. Noia has meant more than giving defendants another chance to cart out their claims. It has enlarged the federalstate dialogue by giving rise to thousands of claims articulated in constitutional terms and assessed by state courts and the inferior federal tribunals.

There are several reasons why federal courts tend to support the utopian end of the dialogue. The federal courts are not themselves as tied to the practical realities of administration of the criminal law as are the state courts. Although the increased activity of the federal criminal law has somewhat obscured this distinction, it is still broadly true. Furthermore, the jurisdiction of the federal court is invoked by

79. State appellate courts, somewhat more remored from "frontline" criminal justice, may sometimes tend toward a utopian perspective. The actuality and potentiality of state utopian developments have been noted by commentators, some dissatisfied with the pragmatic tendencics of the Burger Court. See, e.g., Brennan, State Constitutions and the Protection of Individual Rights, $90 \mathrm{HARv}$. L. REv. 489 (1977); Note, The New Federalism: Toward a Principled Interpretation of the State Constitution, 29 STAN. L. REv. 297 (1977). 
claims about the constitutionality of the state process. The practical aspects of administration are at most a backdrop; the constitutional inquiry is in bold relief. The federal court's inquiry also obscures the defendant's conduct. The guilt, innocence, or dangerousness of the defendant can rarely be the object of focused inquiry in federal court. ${ }^{30}$ Whether desirable or not, ${ }^{\text {s1 }}$ this fact makes it likely that the federal court will be less systematic in construing claims of deprivation of constitutional rights in light of the character of the defendant.

\section{b. The Habeas Corpus Dialogue}

What then are the consequences of such contrary tendencies existing simultaneously in two sets of tribunals both of which have a major part in the criminal process? The structure of habeas corpus jurisdiction determines the consequences. First, no conviction can stand unless both tribunals concur, provided that the federal forum is invoked. This unanimity rule puts the federal courts in an initially strong position. Their decisions may release the particular petitioner and threaten to release other prisoners similarly situated in the state process. The influence of a federal habeas decision may cross state boundaries as well. Since a decision to release a state prisoner is by definition a constitutional pronouncement, a utopian decision anywhere in the system-particularly by a circuit court-must be considered seriously by a state court adopting a pragmatic approach. Even if the utopian decision is not in the circuit in which the state is located, it constitutes a perilous possibility as a precedent unless the home circuit has recently rejected such a rule. The federal system need not be composed solely of utopian courts, therefore, to cxert a utopian tug on state courts. It is this fact that distinguishes utopian decisions from law review articles.

The state courts, however, are not hielpless before federal power. First, the unanimity rule is seriously mitigated in its practical effect by the fact that most state convictions never come before federal courts. Furthermore, the sequential nature of the proceedings means that the federal courts will be confronted with the state system's adjudication of the facts, one that federal courts are neither likely nor permitted to treat lightly. The sequential nature also permits the state to demon-

80. See Developments, supra note 59, at 1057, 1060-61.

81. Judge Friendly has been a strong adrocate of the position that the innocence of the habeas petitioner should affect the federal court's disposition of the claim. Sec Friendly, Is Imnocence Irrelevant? Collateral Allack on Criminal Judgments, 38 U. Cur. L. Rev. 142 (1970); p. 1067 infra. Such a view has gaincd adherents in the Supreme Court. See Stone v. Powell, 428 U.S. 465 (1976); pp. 1086-89 infra. 
strate the practical constraints under which it operates; such pragmatic briefs may elicit acquiescence from the reviewing federal court.

State courts may also openly resist federal utopian decisions. Clearly, state courts are not bound to respect the doctrinal statements of the inferior federal tribunals insolar as they understand those statements not to be compelled by the Supreme Court. As the Florida Supreme Court has recently noted: "It is axiomatic that a decision of a federal trial court, while persuasive if well-reasoned, is not by any means binding on the courts of a State." which the federal court has as to the continued restraint of a petitioner is not the last word with respect to the future orientation of the state court system that generated the case. Such resistance may frustrate federal utopian purposes, particularly if one understands the objective of a utopian decision to be institutional reform-i.e., if the aim of the utopian court is not simply or mainly the release of a given petitioner, but a general change in the practices of a court. Since the federal court lacks administrative supervisory porier over the state courts, and since the political constituencies of the two courts are largely distinct, the reformative strategy of the utopian court can be effectively blocked by state court non-acceptance of a new constitutional rule. While the state court pays a price in released prisoners, it can exact a price from the federal court by frustrating that court's objectives in the majority of cases which will never eventuate in a petition for federal habeas corpus. Thus, therc are incentives for each court system to acknowledge and, if possible, satisfy some of the more reasonable demands of the other. With this approximate equality of power, or at least mutual ability to frustrate, we may expect some movement from original starting points. Even if there is no movement, the elaboration of the respective positions may, over time, inform the Supreme Court with textured experience as well as opposing arguments. The Supreme Court is not, however, simply choosing between competing lower court orientations. The high Court may itself be oriented to either a

82. Bradshaw v. State, 286 So. 2 d 4, 6 (iila. 1973), cerl. denicd, 417 U.S. 919 (1974).

In Mancusi v. Stubbs, 408 U.S. 204 (1972), the defendant's conviction in a Tennessec trial had been overturned by a federal habeas finding of ineffective assistance of counsel. Upon retrial, the State used testimony offered at the first trial by a witness who was not present at the time of the second trial. The defendant was reconvicted. Several years later, the defendant objected to use of the prior conviction in a New lork second-offender sentencing procedure on the ground that the earlier conviction had been based on testimony that should not have been admitted at the second trial because of its unreliability due to the ineffectiveness of counsel at the first trial. The Court, per Justice Rehnquist, held that, under the circumstances, "the State of New York was not bound under any theory of res judicala by [the federal habeas decision] as to the efficacy of the prior cross-cxamination of the witness." Id. at 214. 
pragmatic or utopian perspective on the criminal law. Its orientation will constitute part of a larger dialectic between law and politics which has been a primary subject of constitutional scholarship.

We shall illustrate the hypothesis of the habeas corpus dialogue with two recent examples of the evolution of constitutional doctrine. In both examples we shall see a common pattern at work. (1) Supreme Court decisions set an agenda for the inferior federal courts and the state courts by designating issues and values of particular concern. (2) Federal opinions-and especially circuit court opinions-become the "leading cases" in the evolution of doctrine. (3) A state court reacts to these federal cases, paying particular attention, of course, to the federal court of appeals opinions for the circuit in which it sits, but generally canvassing other circuits as well. State courts generally do not cite or, if they do cite, pay much attention to other state court opinions. (4) Federal courts sometimes respond to persuasive articulation of practical constraints upon state criminal justice, either by explicitly shaping rules to those constraints or by simply not pressing forward with demands. We shall examine this process, first by considering the range of state responses to federal utopian initiatives and then by considering federal response to state pragmatic constraints. Finally, we shall consider the products of this dialogue-not, we fear, any dramatic breakthrough in the ideology of criminal justice, but modest evidence of an ambivalent society considering difficult questions of ideals in practice.

State court decisions take three forms: Sometimes they choose a utopian federal rule (even when not the rule of their circuit), usually quite aware that they do so out of choice not duty. At other times, state courts explicitly reject the utopian rule, even if it is the rule of their circuit. This act is often accompanied by explicit avowal of the power to reject the rule of an inferior federal court. And state courts may acquiesce in a utopian rule out of a practical sense that it is the lesser of two evils-the alternative being federal collateral attack of many convictions. These three forms of state response exist simultaneously in both of the examples we shall examine, and it is a safe conclusion that they co-exist with respect to any issue of complexity.

\section{i. Counsel for Probation and Parole Revocation Hearings}

In the 1967 case of Mempa v. Rhay, ${ }^{\text {s3 }}$ the Supreme Court considered the right to counsel in a revocation of probation proceeding.

83. 389 U.S. 128 (1967). 
The petitioners had pleaded guilty to various offenses and had been placed on probation; imposition of sentence was deferred. When petitioners were charged with committing new crimes on probation, probation was revoked and sentence imposed for the earlier offense in a proceeding without the benefit of counsel. The Supreme Court held that petitioners should have been provided counsel. The case left many issues undecided: whether distinctions should be made between revocation of parole and revocation of probation; whether revocation of parole or probation that entailed only service of a sentence already imposed should require provision of counsel; whether distinctions should be drawn between revocations based upon "technical" violations of parole or probation and revocations resulting from convictions for new crimes where full procedural safeguards had been provided. Finally, the case did not suggest whether a comprehensive rule would cut across the states' many procedural variations in parole and probation revocation or whether a rule would have to be tailored to the processes of each state. The courts were simply left with the general principle that "appointment of counsel for an indigent is required at every stage of a criminal proceeding where substantial rights of an accused may be affected." 84

Some of these questions were answered in Gagnon $v$. Scarpelli, decided by the Court in 1973. But between Mempa in 1967 and Gagnon, the lower federal courts decided dozens of cases on this issue. State courts decided hundreds. The pattern of these cases suggests that the reaction of state to inferior federal courts on a doctrinal level is by no means one of simple coercion. No uniform pattern emerges. Rather, what we see is several paradigmatic responses to Mempa $v$. Rhay. Unlike Supreme Court precedents, lower federal court opinions exercised an impact on many state courts without controlling their decisions. Doctrinal development was a conversation among equals.

The first federal circuit opinions after Mempa $v$. Rhay were split. The Tenth Circuit, in a brief and cryptic opinion, ${ }^{86}$ refused to extend Mempa to parole revocation proceedings that did not involve imposition of sentence. Since the parole revocation at issue reinstated a pre-imposed sentence, the revocation proceeding was "not concerned with sentencing." 87 The court relied in large part on the reasoning

84. Id. at 134; see Townsend v. Burke, 334 U.S. 736 (1948).

85. 411 U.S. 778 (1973).

86. Williams v. Patterson, 389 F.2d 374 (10th Cir. 1968). But cf. Earnest v. Willingham, 406 F.2d 681 (10th Cir. 1969) (appointment of counsel for indigents necessary in proceeding for revocation of mandatory federal release where federal parole regulations permit prisoner to retain counsel).

87. 389 F.2d at 375 . 
that "[p]arole is a matter of grace." 88 The Fifth, ${ }^{80}$ Sixth $^{90}$ and Ninth Circuits took a similarly narrow view of Mempa, limiting it to the special facts of deferred imposition of sentence. The Third Circuit, in an inexcusably shoddy opinion, also implicitly denied the right to counsel to a federal prisoner in a revocation of mandatory release without citing, distinguishing or discussing Mempa $v$. Rhay. ${ }^{92}$

The Fourth Circuit provided the first careful enlargement of Mempa v. Rhay. In Hewett v. North Carolina, ${ }^{93}$ Judge Winter held that the Sixth Amendment required that counsel be provided in all probation revocation proceedings whether or not a new sentence is imposed. The court considered, but rejected, a Betts $v$. Brady ${ }^{04}$ case-bycase approach to the counsel issue. It also rejected any distinction between manifest violations, e.g., those based on subsequent convictions, and violations which require complex factual inquiries. ${ }^{95} \mathrm{Hewett}$ did not consider the question whether parole could be distinguished from probation.

As state courts considered right to counsel claims in parole and probation revocation hearings, Hewett served as the paradigm for a broad reading of Mempa. ${ }^{96}$ The New York Court of Appeals, in a most

88. Id. The grace theory of parole was adhered to by the Tenth, Eighth, and Fifth Circuits until the Supreme Court held otherwise in Morrissey v. Brewer, 408 U.S. 471 (1972). Morrissey, decided one term before Gagnon v. Scarpelli, did not directly involve right to counsel.

89. Shaw v. Henderson, 430 F.2d 1116 (5th Cir. 1970) (revocation of probation).

90. Rose v. Haskins, 388 F.2d 91, 97 (6th Cir.), cert. denied, 392 U.S. 946 (1968) (holding that there is no right to hearing for parole revocation).

91. Eason v. Dickson, 390 F.2d 585, 588 n.3 (9th Cir.), cert. denied, 392 U.S. 914 (1968).

92. United States ex rel. Halprin v. Parker, 418 F.2d 313 (3d Cir. 1969). The court held that a defendant had no right to counsel on the basis of indigency where he had admitted violating parole conditions.

Some of the reluctance on the part of these circuits was due to their unwillingness to become involved in the internal workings of state probation and parole systems. See, e.g., Rose v. Haskins, 388 F.2d 91, 97 (6th Cir.), cert. denied, 392 U.S. 946 (1968) ("Federal Courts cannot be expected to remedy all ills, real or imaginary, in the state's prison disciplinary procedures.") The Tenth Circuit echoed these views. See Williams v. Patterson, 389 F.2d 374,375 (10th Cir. 1968) ("We are unwilling to superintend the administration of a state parole system.") However, in a later decision, the Tenth Circuit ordered a district court to devise appropriate relief for provision of counsel for indigent federal prisoners in parole revocation proceedings despite "the Parole Board's lack of authority to appoint counsel for indigent parolees or the lack of express authority in the courts to make such appointments." Earnest v. Willingham, 406 F.2d 681, 684 (10th Cir. 1969).

93. 415 F.2d 1316 (4th Cir. 1969). Hewett rejected the "grace theory" of probation adhered to by other circuits. Id. at 1322-23.

94. 316 U.S. 455 (1942).

95. 415 F.2d at $1324-25$.

96. The Second and Seventh Circuits adopted the Hewett position two years later. Sce United States ex rel. Bey v. Connecticut State Bd. of Parole, 443 F.2d 1079 (2d Cir.), vacated and remanded with directions to dismiss as mool, 40.4 U.S. 879 (1971) (revocation of parole); Gunsolus : Gagnon, 454 F.2d 416 (7th Cir. 1971), aff'd in part and rev'd in part sub nom. Gagnon v. Scarpelli, 411 U.S. 778 (1973). 
thoughtful opinion, canvassed all federal and a few state opinions and concluded that Hewelt was the better reading of Mempa.97 Chief Judge Fuld went a bit further and concluded that Hewett ought to apply to parole as well as probation revocations. Hewett did not, however, have the effect of imposing a constitutional order even upon the states of the Fourth Circuit. The Maryland Court of Special Appeals in Knight $v$. State had carefully analyzed the implications of Mempa $v$. Rhay for revocations of probation and declined to extend it beyond the narrow facts there presented ${ }^{98}$-sentence imposition. It reconsidered the matter after Hewett: "We have considered the question, and although a decision of the Fourth Circuit is entitled to respect, it is not binding upon us. ... [W] [ecline to overrule Knight."99

State courts in other circuits also felt the necessity to engage Hewett. Before Hewett the Nevada State Supreme Court had considered the question of the right to counsel at revocation of probation hearings, opting for a narrow rule. ${ }^{100}$ After Mempa and Hewett, the court was asked to reconsider; it explicitly stated, "We are bound by the decisions of the United States Supreme Court .... . We are not bound by the decisions of the other federal courts." 101 Other state courts reacted differently. Just as the New York Court of Appeals had decided to accept the reasoning of Hewett though it was neither binding nor a majority view, so Pennsylvania also accepted this expansive reading of the principles of Mempa $v$. Rhay as to parole revocations, ${ }^{102}$ despite apparent Third Circuit authority to the contrary. ${ }^{103}$

The influence of habeas corpus on state law can be seen most dramatically in the response of the Wisconsin State Supreme Court. That court, citing a recent Seventh Circuit opinion, ${ }^{10 \pm}$ invalidated some of the existing practices of state probation and parole revocations and required that limited hearings be provided. However, the court limited Mempa to its facts; it held that there is a right to

97. Pcople ex rel. Menechino v. Warden, 27 N.Y.2d 376, 267 N.E.2d 238, 318 N.Y.S.2d 149 (1971).

98. Knight v. State, 7 Md. App. 313, 321, 255 A.2d 441, 446 (1969).

99. Dugas v. State, 12 Md. App. 165, 167, 277 A.2d 620, 621-22 (1971).

100. See Smith $v$. Warden, 85 Nev. 83,450 P.2d 356, cert. denied, 396 U.S. 860 (1969); In re DuBois, 84 Nev. 562, 445 P.2d 351 (1968).

101. Bargas v. Warden, 87 Nev. 30, 31-32, 482 P.2d 317, 318, cert. denied, 403 .U.S. 935 (1971).

102. See Commonwcalth ex rel. Rambcau v. Rundle, 455 Pa. 8, 16-19, 314 A.2d 842, 816-47 (1973).

103. See Unitcd States ex rel. Halprin v. Parker, 418 F.2d 313 (3d Cir. 1969).

10t. Hahn v. Burke, 430 F.2d 100 (7th Cir. 1970), cert. denied, 402 U.S. 933 (1971). 
counsel only for sentence imposition ${ }^{105}$ and rejected the minority view of Hewett and two Wisconsin federal district courts. ${ }^{106}$

Very shortly after that opinion the Seventh Circuit decided the case of Gunsolus $v$. Gagnon ${ }^{107}$ (which was to be reversed in part by the Supreme Court in Gagnon v. Scarpelli). The Seventh Circuit, affirming the district court opinions that the state court had ignored, laid down a rule which required counsel in all probation revocation hearings. The Seventh Circuit cited Hewett and other Sixth Amendment cases that had followed it. But its holding mainly relied upon the argument that revocation of parole and probation implicates a due process right to a hearing and counsel. ${ }^{108}$

The Supreme Court of Wisconsin acquiesced in the decision of the Seventh Circuit. In two decisions rendered between the Seventh Circuit's decision in Gunsolus and its partial reversal by the United States Supreme Court in Gagnon v. Scarpelli, the Wisconsin Supreme Court accepted the rule of the Seventh Circuit. It initially extended the rule to juvenile proceedings analogous to revocation of probation $^{109}$ and then to all probation revocation proceedings. ${ }^{110}$ But it was not clear until after the United States Supreme Court's opinion in Gagnon $v$. Scarpelli precisely how the Wisconsin Supreme Court perceived its relationship to the federal court of appeals.

The Supreme Court in Scarpelli held that the question whether counsel must be provided in parole or probation revocation should be determined on a case-by-case analysis of the need for counsel in any particular instance. The Court explicitly likened the analysis to the pre-Gideon case-by-case approach required under Betts $v$. Brady.111 After Scarpelli the Wisconsin Supreme Court was confronted with the question whether its precedents, decided in the wake of the Seventh Gircuit's opinion, remained good law. The Wisconsin court held that the earlier opinions had been rendered in deference to the Seventh Circuit and in the interest of the harmonious ordering of federal-state

105. State ex rel. Johnson v. Cady, 50 Wis. $2 d$ 540, 547-48, 553-54, 185 N.W.2d 306, 310, 313-14 (1971) (although due process requires a hearing prior to parole or probation revocation, counsel not required).

106. Goolsby v. Gagnon, 322 F. Supp. 460 (E.D. Wis. 1971); Scarpelli v. Gagnon, 317 F. Supp. 72 (E.D. Wis. 1970), aff'd sub nom. Gunsolus v. Gagnon, 454 F.2d 416 (7th Cir. 1971), aff'd in part and rev'd in part sub nom. Gagnon v. Scarpelli, 411 U.S. 778 (1973).

107. 454 F.2d 416 (7th Cir. 1971), aff'd in part and rev'd in part sub nom. Gagnon v. Scarpelli, 411 U.S. 778 (1973).

108. Id. at 421-22.

109. State ex rel. Bernal v. Hershman, 54 Wis. 2d 626, 630, 196 N.W.2d 721, 723-24 (1972) (revocation of "liberty under supervision" for juveniles).

110. Oestrich v. State, 55 Wis. 2d 222, 198 N.W.2d 664 (1972) (applying Bernal to probation revocation).

111. 411 U.S. at 788-91. 
court relations. ${ }^{112}$ (Clearly harmony would have been threatened by disregarding the circuit court of appeals decision; such disregard presented the likelihood of subsequent habeas corpus petitions effectuating the release of state prisoners.) Although the majority of the Wisconsin court retreated to the requirements of Scarpelli, they did not characterize their prior position as having been compelled by the Seventh Circuit. Rather, they explicitly understood it to have been a voluntary acquiescence in the circuit's rule-acceptance determined not "on the basis of an independent judgment or policy"113 but by the exigencies of the relationship created by federal habeas corpus.

The three responses of non-acceptance of, agreement in, and pragmatic acquiescence in inferior federal court constitutional doctrine are thus exemplified respectively by the Maryland, New York, and Wisconsin experiences. But influence was hardly in one direction only. The Fourth Circuit, which had staked out broad ground in Hewett, had occasion to reconsider that ground in the closely analgous case of revocation of parole rather than probation. In an en banc decision, Bearden v. South Carolina, ${ }^{114}$ the court held that parole revocation was distinguishable from probation revocation and that counsel was not available as of right. The court distinguished Hewett on the ground that probation revocation is a stage in a criminal proceeding, while parole revocation occurs "after every stage of the trial has been completed." 115 Of the panel which decided Hewett, two members joined the majority in Bearden while the author of Hewett, Judge Winter, dissented.

A major element in the majority opinion in Bearden is acknowledgment of the practical difficulties of enforcing a right to counsel requirement in administrative proceedings which often take place long after the original criminal trial. As the court stated:

If it should ever be decided that every parolee must have free counsel furnished by the state, it seems to us that the burden should not be thrust wholly upon original trial counsel, who is scarcely better able to function than would new counsel and is likely to be far removed from the venue of the parole revocation hearing. Moreover, we doubt the inherent power of the courts to compel counsel as officers of the judicial branch to perform services without compensation in the executive branch of govern-

112. State $e x r e l$. Cresci v. Schmidt, 62 Wis. $2 \mathrm{~d} 400,411-13,215$ N.W.2d $361,365-67$ (1974).

113. Id. at $410-11,215$ N.W.2d at 365 .

114. 443 F.2d 1090 (4th Cir. 1971) (en banc), cert. dismissed, 405 U.S. 972 (1972).

115. Id. at 1092, 1094 . 
ment. So far as we know, neither South Carolina nor Virginia, nor any of the other states within this circuit, have legislatively authorized the payment of lawyers to represent parolees faced with the possibility of revocation. Thus if the Constitution compels representation by counsel, it will compel lawyers to work in nonjudicial business without compensation, at least until such time, if ever, as the legislatures of the several states may appropriate voluntarily or under court order monies for such a purpose. ${ }^{110}$

It is hardly likely that a similar opinion would have been written had the states of the Fourth Circuit greeted Hewett as did the New York Court of Appeals or the Pennsylvania Supreme Court. The out and out resistance of a state like Maryland to Hewett must have caused some second thoughts on the prospect for reform. Most important, however, the Fourth Circuit had clearly run up against the limits of habeas corpus as a mechanism for reform. The response to Hewett had made it evident that only a coercive strategy would accomplish the change. And court orders to set up counsel provision systems, the Fourth Circuit realized, would be a different game altogether. ${ }^{117}$

\section{ii. Effective Assistance of Counsel}

A similar dialogue can be seen in the redefinition of effective assistance of counsel over the past decade. Federal and state courts began to reconsider traditional notions of the adequacy of counsel after the Supreme Court's 1963 ruling in Gideon v. Wainwright, ${ }^{118}$ which established the indigent's right to assistance of counsel in criminal cases. For decades courts understood that the right to counsel, to be

116. Id. at 1092-93 (emphasis added).

117. There are many other examples of fedcral recogriition of state intransigence. On the closely analogus question whether parole can be revoked without a hearing, the Eighth Circuit sitting en banc refused to find a right to a hearing. Morrissey v. Brewer, 443 F.2d 942 (8th Cir. 1971), rev'd, 408 U.S. 471 (1972). The court noted that Iowa's parole statutes provided for rehcaring and that "the legal procedures providing for parole are part of the legislative function of creating a penological system." Id. at 947. It further stated that requirement of a hearing would overburden statc and fedcral courts and "be contrary to the basic principle of comity between the federal and state governments." Id. at 951 . The court's fear of disrupting harmonious relations was real. Iowa courts had repeatedly refused to recognize any rights to notice or a hearing prior to parole or probation revocation. And the State Supreme Court had stated its intention to maintain this position "unless it appears the United States Supreme Court has precmpted this arca of the law." Cole v. Holliday, $171 \mathrm{~N} . \mathrm{W} .2 \mathrm{~d} \mathrm{603,606}$ (Iowa 1969) (cited in Morrissey v. Brewer, 443 F.2. at 944 n.3).

118. 372 U.S. 335 (1963). For a thorough discussion of the changing effective assistance standard, see Bines, supra note 28. 
meaningful, had to imply "effective" assistance; 119 yet the traditional test-whether counsel's actions rendered the trial a "farce and mockery" of justice-practically insulated the acts of defense counsel from subsequent attack. While as early as 1960 the Fifth Circuit had articulated a standard of "reasonably effective assistance,"120 dramatic changes did not occur until 1970 with the Third Circuit's opinion in Moore $v$. United States ${ }^{121}$ and the Supreme Court's dictum in McMann $v$. Richardson that defendants are due advice that is "within the range of competence demanded of attorneys in criminal cases."122

The new focus on counsel seemed particularly appropriate in light of the Brady Trilogy ${ }^{123}$ and Tollett $v$. Henderson. ${ }^{124}$ These opinions legitimated the resolution of the vast majority of criminal cases by way of a negotiated plea, and held that guilty pleas would be immune from attack except upon a showing of inadequate assistance of counsel. Accordingly, courts would be asked to scrutinize counsel's actions. As the Fifth Circuit recognized, "One cannot read [the Brady Trilogy] without being impressed by the significance the Court attached to the role of counsel in the process of deciding how to plead." 125 The Courts of Appeals for the Third, ${ }^{126}$ Fifth, ${ }^{127}$ Sixth, ${ }^{128}$ and District of Columbia Circuits ${ }^{129}$ led the move to a new effective assistance of counsel standard. As with the evolution of the right to counsel in probation and parole proceedings, three different state court responses can be identified.

119. This was recognized by the Supreme Court as early as Powell v. Alabama, 287 U.S. 45, 53 (1932). See Bazelon, The Realities of Gideon and Argersinger, 64 GEo. L.J. 811, 818-19 (1976).

120. MacKenna v. Ellis, 280 F.2d 592, 599 (5th Cir. 1960), modified per curiam en banc 289 F.2d 928 (5th Cir.), cert. denied, 368 U.S. 877 (1961).

121. 432 F.2d 730, 736 (3d Cir. 1970) ("level of competency . . . generally afforded at the bar to fee-paying clients").

122. 397 U.S. 759, 771 (1970) (dictum). For a recent restatement, see Henderson v. Morgan, 426 U.S. 637, 656 (1976) (Rehnquist, J, dissenting) (test is "based on the practices of reasonably competent attorneys experienced in the day-to-day business of representing criminal defendants in a trial court").

The newer standard, which subjects counsel's actions to closer scrutiny, is denominated in a variety of ways. This article shall adopt the phrase "reasonable competence" to stand for the various formulations. For a collection of these formulations, see Bazelon, supra note 119 , at $819-20$.

123. Brady v. United States, 397 U.S. 742 (1970); McMann v. Richardson, 397 U.S. 759 (1970); Parker v. North Carolina, 397 U.S. 790 (1970).

124. 411 U.S. 258 (1973).

125. Colson v. Smith, 438 F.2d 1075, 1079 (5th Cir. 1971) (emphasis in original).

126. See Moore v. United States, 432 F.2d, 730, 735-37 (3d Cir. 1970).

127. See West v. Louisiana, 478 F.2d 1026 (5th Cir. 1973), vacated in part and aff'd in part en banc per curiam, 510 F.2d 363 (5th Cir. 1975).

128. See Beasley v. United States, 491 F.2d 687, 696 (6th Cir. 1974).

129. United States v. DeCoster, 487 F.2d 1197, 1202-04 (D.C. Cir. 1973). 
Although the Fifth Circuit in MacKenna v. Ellis had adopted the reasonable competence standard, ${ }^{130}$ a number of Fifth Gircuit cases continued to apply the "farce and mockery" standard through the 1960s. ${ }^{131}$ In 1974 several cases made clear that the MacKenna rule was the law of the circuit. ${ }^{132}$ The Georgia courts demonstrated the "acquiesced in" response to the Fifth Circuit's new standard.

The traditional test in Georgia had been tantamount to the "farce and mockery" standard. ${ }^{133}$ However, in Pitts $v$. Glass ${ }^{134}$ the Georgia Supreme Court adopted the new Fifth Circuit formulation. The shift was less than explicit. The court first noted that the appellant claimed that under the Fifth Circuit rule he was denied effective assistance of counsel, then observed that "this court has previously recognized many times" the right to "effective" counsel, and finally affirmed the conviction. ${ }^{135}$ Later opinions made clear that the reasonable competence standard had been adopted in Pitts. ${ }^{136}$

The Florida courts, however, have resisted the Fifth Circuit's changes. In two recent terse opinions, ${ }^{137}$ the Florida appellate courts have adhered to a 1973 Florida appellate court decision, Caplinger $v$. State, ${ }^{138}$ which applied the farce and mockery standard to retained counsel. The Florida courts were certainly aware of the Fifth Circuit rule. Indeed, a 1972 Fifth Circuit case had indicated that, upon remand, the district court should use the reasonable competence standard in evaluating the adequacy of counsel in a Florida trial. ${ }^{139}$ Yet Florida opinions have not acknowledged the Fifth Circuit's rule. This is even more significant when contrasted with the Caplinger decision's reliance on Fifth Circuit rulings in deciding another issue

130. 280 F.2d 592, 599 (5th Cir. 1960), modified per curiam en banc, 289 F.2d 928 (5th Cir.), cert. denied, 368 U.S. 877 (1961).

131. See, e.g., Foster v. Beto, 412 F.2d 892 (5th Cir. 1969); Busby v. Holman, 365 F.2d 75, 79 (5th Cir. 1966); Williams v. Beto, 354 F.2d 698, 704 (5th Cir. 1965).

132. See, e.g., Lee v. Hopper, 499 F.2d 456 (5th Cir.), cert. denied, 419 U.S. 1053 (1974); Herring v. Estelle, 491 F.2d 125 (5th Cir. 1974); West v. Louisiana, 478 F.2d 1026, 1033 (5th Cir. 1973).

133. See, e.g., Givens v. Dutton, 222 Ga. 756, 758, 152 S.E.2d 358, 359.60 (1966).

134. 231 Ga. 638, 203 S.E.2d 515 (1974).

135. Id. at 639-40, 203 S.E.2d at 516-17.

136. See, e.g., Tamplin v. State, 235 Ga. 20, 25, 218 S.E.2d 779, 783 (per curiam), on extraordinary motion for rehearing, reaff'd in part and vacated in part per curiam, 235 Ga. 774,221 S.E.2d $455(1975)$.

137. Johnson v. State, 328 So. 2d 33 (Fla. Dist. Ct. App. 1976) (per curiam); Andrews v. State, 319 So. $2 d 613$ (Fla. Dist. Ct. App. 1975) (per curiam).

138. 271 So. $2 d 780$ (Fla. Dist. Ct. App. 1973) (per curiam).

139. Sloan v. Wainwright, 469 F.2d 390 (5th Cir. 1972) (per curiam); see Murray v. Florida, 384 F. Supp. 574 (S.D. Fla. 1974) (applying Fifth Circuit standard in review of counsel's acts in Florida trial; no ineffective assistance found). 
in the case: the extent to which a substituted judge had to inform herself about the case before sentencing the defendant. ${ }^{140}$ One must conclude, therefore, that the Florida courts do not regard themselves bound by the Fifth Circuit's declarations of constitutional doctrine. ${ }^{141}$

Florida courts' resistance to the Fifth Gircuit's standard for effectiveness of counsel is most blatant in their adherence to a rule denying any remedy for ineffectiveness of privately retained counsel. In United States ex rel. Reis $v$. Wainwright, ${ }^{142}$ the Fifth Circuit held that the petitioner did not have to present her claim of incompetent retained counsel to the state courts before seeking federal habeas relief because such a resort to state remedies would be futile:

In an uninterrupted line of cases Florida has steadfastly refused to recognize incompetence of privately retained counsel as a valid basis for post-conviction relief. The rule appears firmly entrenched in Florida's jurisprudence, and we see no indication that a Florida appellate court would be inclined to deviate from this well worn path.

$\ldots$ The rule has been maintained in Florida, even in the face of holdings of this circuit that a defendant who is denied due process because of the incompetency of privately retained counsel is as deserving of post-conviction relief as a defendant who has had court-appointed counsel $\ldots .{ }^{143}$

The federal court admitted that it could do no more than grant writs of habeas corpus. "At any rate our decisions would not bind the Florida state courts," it observed, citing two Florida cases stating that federal decisions were due respect but not allegiance. ${ }^{144}$

In sharp contrast to Florida's resistance, a state may choose a liberal rule, persuaded by the weight of federal authority, even in the absence of a federal threat to release prisoners. For example, the courts of Connecticut sit in one of the circuits which has recently and adamantly held to a "farce and mockery" standard.145 Nevertheless, in 1976 the Connecticut Supreme Court adopted the reasonable competence standard, based upon an exhaustive analysis of the various circuit rules

140. 271 So. $2 \mathrm{~d}$ at 781 .

141. See Bradshaw v. State, 286 So. $2 d$ 4, 6 (Fla. 1973), cert. denied, 417 U.S. 919 (1974) (quoted at p. 1049 supra).

1.12. 525 F.2d 1269 (5th Cir. 1976).

143. Id. at $1272-73$ (footnotes omitted).

144. Id. at 1272 n.l1.

145. Compare United States v. Wight, 176 F.2d 376, 379 (2d Cir. 1949), cert. denied, 338 U.S. 950 (1950) with Lunz v. Henderson, 533 F.2d 1322, 1327 (2d Cir.), cert. denied, 429 U.S. 849 (1976). 
and law review commentaries. ${ }^{146}$ Similarly, the Supreme Court of Tennessee canvassed the eleven circuits, noticed the trend away from farce and mockery, and overruled earlier state decisions in light of the "better reasoning" of the reasonable competence cases. The Sixth Circuit happened to have adopted this liberal rule, but the Tennessee court paid it no greater attention than it paid the other circuits. ${ }^{147}$

In the "effective assistance" cases, federal court opinions, especially circuit court opinions, have served as foci for constitutional dialogue with state courts all over the nation. Many of the significant federal decisions relied upon by state courts were not habeas corpus review of state convictions. But it is federal habeas corpus jurisdiction that establishes the relevance of federal constitutional decisions regarding effective assistance of counsel. ${ }^{148}$ Unless cases explicitly relied on the circuit courts' supervisory powers over federal trial courts, federal habeas corpus guaranteed that a circuit court opinion would create a measure for the state system whether articulated in a federal case or in a habeas review of a state conviction. So long as federal courts intimated that they would apply the same standards in state and federal cases, the structure of habeas corpus gave force to the federal utopian tug.

\section{iii. The Impact of the Dialogue}

One may conclude from the examples above that the utopian constitutional perspective emerged largely from the federal courts. Even though a majority of federal decisions took the pragmatic view as to provision of counsel for parole revocations, Hewett was the preeminent utopian statement. Both Hewett and Gunsolus were far more influential decisions than the equally far-reaching decisions of the New York Court of Appeals and the Pennsylvania Supreme Court. State courts like those of Maryland and Nevada felt no need to converse with other state courts, but they did feel compelled to confront the Fourth Circuit's views before rejecting them. And needless to say, the Wisconsin Supreme Court's doctrinal shift would not have been in-

146. State v. Clark, 170 Conn. 273, 280-83, 365 A.2d 1167, 1170-72, cert. denied, 425 U.S. 962 (1976). Vermont has also moved to the reasonable competence standard despite the Second Circuit's adherence to farce and mockery. See In re Cronin, 336 A.2d 164, 168-69 (Vt. 1975) (citing no Second Circuit cases).

147. Baxter v. Rose, 523 S.W.2d 930, 936 (Tenn. 1975).

148. Besides the threat of release of prisoners by a writ of habeas corpus, there are other reasons why the federal circuit decisions are specially noted by the states. First, there are relatively few circuit court foci-enough to make it likely that a plausible constitutional view will be aired, but few enough to canvass easily. Second, federal judges do, in general, have somewhat more stature than all but a handful of state judges. 
duced by Gunsolus had that opinion been written by a state court. Most impressive, however, is the evidence from the adequacy of counsel cases. Despite a large preexisting case law on this subject, the state cases in the past ten years have consistently canvassed and considered leading federal cases moving away from "farce and mockery." It is far less common to see a sister state case cited.

We have also seen that doctrinal evolutions of the adequacy of counsel standard and of Mempa $v$. Rhay remained fluid in a manner not possible after the Supreme Court has decided an issue. The fluidity arose from both the polycentric character of federal law in the absence of controlling Supreme Court rules and from the fact that state courts can and do respond independently to federal circuit law. 'Taken together, the state and federal opinions demonstrate a remarkable breadth of views and concerns. The remand for further scholarly debate that Alexander Bickel cited as a justification for the passive virtues in exercising judicial review ${ }^{149}$ appears to be achieved through the modest vehicle of federal habeas corpus.

The scholarly debate is not solely an academic exercise. While the Supreme Court may define the values from which a dialogue will proceed, the ensuing dialogue will have a profound impact on the development of constitutional law. This can be seen in the movement over the past decade in the effectiveness of counsel cases. With several federal circuits leading the way, a significant shift in doctrine has occurred in the federal and state courts with no more than dicta from the Supreme Court to guide it. In light of this development, it would be far easier today for the Court to explicitly hold the farce and mockery standard impermissible than it would have been ten years ago.

The consequences of the dialogue need not point in a utopian direction. In the intervening years between Mempa and Gagnon the dialogue permitted state and lower federal courts to evaluate and discuss experiences, to inform the Supreme Court of the pragmatic and utopian perspectives. By the time the Court decided Gagnon, it was faced with mixed emotions on the federal level and some states' resistance to the broadest interpretation of Mempa $v$. Rhay. The Court took a middle approach, perhaps enriched by the type of concerns that confronted the Fourth Circuit in Bearden. Its utopian extension was tempered by pragmatic considerations:

In some cases, these modifications in the nature of the revocation hearing must be endured and the costs borne .... But due

119. See A. BiCKEL, supra note 65, at 69-7?. 
process is not so rigid as to require that the significant interests in informality, flexibility, and economy must always be sacrificed.

...

... We think ... that the decision as to the need for counsel must be made on a case-by-case basis in the exercise of a sound discretion by the state authority charged with responsibility for administering the probation and parole system. ${ }^{150}$

The decision represents not only a compromise but also a remand for still another constitutional dialogue. ${ }^{\mathbf{1 5 1}}$

The dialogue itself, regardless of its effect on the development of constitutional doctrine, may be justified because it articulates a basic tension in our society's view of the criminal process. We are deeply troubled by the implications of constitutional values in the criminal law. The parallel forum in the criminal law permits society to enact, ritualize, project its own ambivalence in jurisdictional terms. The dialectical federalism of Fay $v$. Noia permits us both to act as if we were not committed to these uncertain constitutional values and to cherish them as indispensable. We try on both garments. And it is surprising how often both fit-how clearly each image of the process makes perfect sense so long as we suppress the other. Hewett $v$. North Carolina and Bearden $v$. South Carolina are both sensible and sound decisions. They are troublesome primarily because they are the product of the same court within the space of two years. We cannot, once we know this, read one opinion without recalling the other. But just as both waves and particles are complementary, necessary, models to adequately account for the behavior of light, so utopian and pragmatic perspectives on the criminal process may both be indispensable to a complete account of our ambivalent and contradictory social selves. If we are in such a state, it may be as foolish to give up one of our "redundant" forums as it would be for the physicist to forgo either his wave or his particle model. Thus the Warren Court's movement to

150. Gagnon v. Scarpelli, 411 U.S. 778, $788-90$ (1973).

151. The effect of federal habeas decisions on the development of constitutional doctrine may be more direct. For example, in Brady v. Maryland, 373 U.S. 83, 87 (1963), the Supreme Court ruled that a prosecutor's failure to disclose exculpatory evidence to the defense upon request violated due process, irrespective of the good or bad faith behind the action. The decision was an extension of Mooney v. Holohan, 294 U.S. 103, 112 (1935), which had found that a prosecutor's suppression of exculpatory evidence, where it amounted to "deliberate deception" of the jury, violated the Fourteenth Amendment. In Brady, the Court affirmed a decision by the Maryland Court of Appeals, which had relied upon two Third Circuit state habeas decisions, Brady v. State, 226 Md. 422, 426-27, 174 A.2d 167, 169 (1961), aff'd, 373 U.S. 83 (1963) (citing United States ex rel. Almeida v. Baldi, 195 F.2d 815 (3d Cir. 1952), cert. denied, 345 U.S. 904 (1953), and United States ex rel. Thompson v. Dye, 221 F.2d 763 (3d Cir.), cert. denied, 350 U.S. 875 (1955)). 
habeas corpus may have been due to its inability to settle us or itself into an unambiguous commitment to equality in the criminal law.

\section{c. The Dialogue and the Commentators}

The constitutional dialogue sketched above is largely ignored by the scholarly debate of the commentators. Both defenders and detractors of Fay and Brown v. Allen have assumed that we have some pre-existing catalog of federal rights and the problem is one of reliable enforcement. The pro-Fay forces, best characterized by Justice Brennan, stress the importance and particular characteristics of a federal forum to hear federal constitutional claims or they posit the unreliability of state courts in properly adjudicating such claims. ${ }^{152}$ But this position fails to appreciate the role of habeas corpus in the creation of constitutional rights. The issue in all of the cases we have considered was not whether the unquestioned rule of Mempa $v$. Rhay should be applied or whether MCMann required a certain definition of adequacy. In both situations the courts knew they were treading on terra paene incognita. The trustworthiness of state courts is irrelevant. Even if state courts are entirely trustworthy in applying Supreme Court doctrine, they would not evolve the underlying principles in the same way without the habeas dialogue.

Critics of Fay's redundancy fall into two categories. There are those, represented by Judge Henry Friendly, who would argue that there is no reason to consider reduction of constitutional error an end in itself. In the context of collateral attacks, the major value ought to be whether there is the requisite certainty that an innocent man has not been convicted. ${ }^{153}$ While this position is plausible as an organizing principle for an approach to collateral relief, and perhaps criminal law in general, its implications are not necessarily to limit the extent of redundancy through habeas corpus. Indeed, such an "innocencerelevance" perspective, as will be discussed in Part II, has the potential for creating new rights and expanding categories of collateral relief. Just as the value of equality could direct the utopian/pragmatic dialogue, so can any other coherent set of values. A second group of commentators and courts criticize the redundancy of Fay for its intrusiveness into state affairs, its waste of judicial resources, and the

152. See, e.g., Fay v. Noia, 372 U.S. 391, 424 (1963); Stone v. Powell, 428 U.S, 465, 52526 (1976) (Brennan, J., dissenting); Note, Stone v. Powell and the New Federalism: $A$ Challenge to Congress, 14 Häv. J. LeGis. 152, 162-64 (1976).

153. See Friendly, supra note 81; see also Schneckloth v. Bustamonte, 412 U.S. 218, 258 (1973) (Powell, J., concurring). 
indeterminancy it lends to the criminal process. ${ }^{154}$ These critics favor a general cutback in collateral relief. Clearly such a view ignores the benefits of the dialogue sketched above. An indiscriminate evisceration of the rule of Fay will hamper the cooperative definition of constitutional rights engaged in by the states.

The critics of Fay appear ascendant. The Burger Court has acted broadly and with vigor in recent Terms in cutting back collateral attack of state convictions. The next part of this article will consider the recent decisions and their implications for the regime of Fay $v$. Noia.

\section{The Burger Court}

The appointment of Chief Justice Burger to the Court brought an end to the reform strategy of the Warren Court. From 1969 to the present a new majority has formed and coalesced. It has reacted strongly to the juridical personality of its predecessor. Norwhere has the reaction been as evident and persistent as in the criminal law.

A reconstituted Supreme Court may be expected to reorient the terms of constitutional dialogue as it imposes its stamp upon doctrine. At first, we assume, this process will take the form of criticism of the work of predecessor Courts. Eventually, however, if a Court is to develop its own identity, it must shape from this reactive criticism a coherent set of values which will themselves constitute a jurisprudence. Whether the jurisprudence begins as critical or apologetic, utopian or pragmatic, it must carry with it, as all ideas do, the potential capacity to be used both for and against existing orders, both for and against any particular vision of the future. If a Court's ideas do not entail such possibilities, and if the possibilities are not realized to some extent, the Court is justly open to attack as politicized, nonneutral, and ultimately incoherent.

In this section we shall examine the Burger Court's reactions to and criticisms of Fay's redundancy. We shall attempt to discern from the body of law that the Court has created since 1969 an emerging jurisprudence-an idea or ideas with the potential for utopian as well as pragmatic applications; ideas which might become the basis for a reoriented dialogue. We shall first consider what the Court has done with or to Fay itself. Next we shall outline two important ideas-waiver and guilt/innocence-which have infused the case law of this period. We

154. See Schneckloth v. Bustamonte, 412 U.S. at 259-66 (Powell, J., concurring); Bator, supra note 58, at 525; Friendly, supra note 81 , at 146-49. 
shall contend that an honest application of either of these ideas has remedial implications as far-reaching as $F a y$ itself.

\section{A. The Erosion of Fay v. Noia}

\section{The Guilty Plea Cases}

The Burger Court's attack upon broad federal habeas review of state convictions began in 1970 with the Brady Trilogy. ${ }^{155}$ The Trilogy, in legitimating the plea bargain, created an enormous exception to the rule of Fay. Fay appeared to have held that a right would not be waived unless that waiver was knowing and voluntary under the Johnson v. Zerbst standard. ${ }^{150}$ Simply forgoing an opportunity or forum for raising the federal claim was not, itself, conclusive as to one's knowledge and intention. Defendant Noia had certainly knowingly and intelligently forgone a state appeal, but he had not thereby voluntarily forgone his coerced-confession claim. Justice Brennan, for the Fay Court, held that the fact that pursuing the appeal would have entailed serious risk of a death sentence upon retrial was sufficient, as a matter of federal law, to excuse the bypass of the state procedure. ${ }^{15 T}$

In the Burger Court's guilty plea cases, in contrast, the Court stated that waiver of the forum in which to raise the claim (the trial) bars subsequent litigation of the rights themselves. Thus the Court found forgoing the plea of not guilty and a trial to be qualitatively different from the waiver of other state procedures for raising a federal claim. In McMann v. Richardson, ${ }^{158}$ the Court held that a knowing and voluntary guilty plea, entered upon advice of competent counsel, extinguished the right to raise a coerced-confession claim on federal habeas corpus. In a second Brady Trilogy case, Parker v. North Carolina, ${ }^{159}$ the reason the defendant had forgone a trial and consequently his coerced-confession claim was the fear of a possible death sentence. The parallel to $F a y$ was striking. Yet the Court held the plea to have extinguished the antecedent coerced-confession claim.

Excepting guilty pleas from the rule of Fay could be justified on two distinct theories. A guilty plea could be viewed as a "break in the chain of events which has preceded it in the criminal process"-a break

155. Brady v. United States, 397 U.S. 742 (1970); McMann v. Richardson, 397 U.S. 759 (1970); Parker v. North Carolina, 397 U.S. 790 (1970).

156. 372 U.S. at 439 (citing Johnson v. Zerbst, 304 U.S. 458,464 (1938)).

157. Id. at 396 n.3, 439.40 .

158. 397 U.S. $759,768.69$ (1970).

159. 397 U.S. $790,794.95$ (1970). 
that extinguishes the opportunity to raise antecedent constitutional claims. ${ }^{160}$ This "break in the chain of events" approach has all the attributes of an implied waiver theory, although the Court has avoided using that term lest the language of Johnson v. Zerbst or Fay be thrown in its face. This waiver theory is founded in concerns with finality and efficiency in the criminal process. The mass administration of justice requires quick and certain punishment-an end to adjudication and the beginning of rehabilitation. Alternatively, the guilty plea may be seen as an adequate index of the defendant's guilt. For an innocent defendant, the theory holds, would not plead guilty in a voluntary, intelligent, counseled act. Antecedent constitutional claims are simply irrelevant, since guilt has been properly established.

It is natural to find both "waiver" and "guilt/innocence reliability" put forward as overlapping rationales for the guilty plea. The plea could not make sense without some concept of waiver since all concede that even a clearly guilty man has the right to a trial. Conversely, few would contend that a judge should or must accept a guilty plea when there is evidence before the court that convinces the judge of the defendant's innocence. ${ }^{161}$

The two theories are often complementary. In Tollett $v$. Henderson, ${ }^{162}$ the petitioner, a black man, claimed to have been indicted for first-degree murder by an unconstitutionally composed grand jury in 1948. No black person had even served on a grand jury in the county despite a population that was $25 \%$ black. ${ }^{163}$ Justice Rehnquist wrote for the Court denying collateral relief and stressing that the plea, when voluntarily and intelligently made, should be final and extinguish all antecedent claims. ${ }^{164}$ His opinion relies primarily upon an efficiency rationale. In doing so, it logically determines the results of all cases raising antecedent constitutional claims so long as the circumstances of the guilty plea are consistent with the controlling standards of voluntariness, intelligence, and right to counsel.

160. Tollett v. Henderson, 411 U.S. 258, 267 (1973).

161. See North Carolina v. Alford, 400 U.S. 25, 38 n.Il (1970):

Our holding [that a guilty plea may be accepted even if the defendant insists that he is innocent] does not mean that a trial judge must accept every constitutionally valid guilty plea merely because a defendant wishes so to plead. A criminal defendant does not have an absolute right under the Constitution to have his guilty plea acepted by the court. ...

The courts of appeals have generally left federal judges with discretion to refuse guilty pleas. See e.g., United States v. Martinez, 486 F.2d 15, 20 (5th Gir. 1973) (dictum); United

States v. Bednarski, 445 F.2d 364, 365-66 (Ist Cir. 1971).

162. 411 U.S. 258 (1973).

163. Id. at 274 (Marshall, J., dissenting).

164. Id. at 266-67. 
Tollett, however, can also be reconciled with the guilt/innocence theory. According to this theory, the primary rationale for validating guilty pleas is that the plea, if properly made, removes the issue of "factual guilt" from the case. Insofar as one holds that the only valid function of a grand jury is to determine whether there is probable cause to believe that an offense was committed and that the defendant committed it, ${ }^{165}$ the establishment of factual guilt by the plea moots any grand jury claims. Hence, they are not cognizable in habeas corpus.

As recent cases have made apparent, however, the two approaches can be fundamentally at odds. In a per curiam opinion, Menna $v$. New York, ${ }^{136}$ holding that a double jeopardy claim was not extinguished by a guilty plea, the Court had to determine whether it was an implied waiver theory or guilt/innocence values which had been at the basis of earlier results extinguishing antecedent constitutional claims. The waiver doctrine cut against recognition of the double jeopardy claim: there is nothing about the guilty plea understood as an implicit waiver that distinguishes double jeopardy from any other claim.

In the face of this logic, advocated in a similar case by Justice Rehnquist, ${ }^{107}$ the Court squarely rejected the waiver theory and held earlier cases to have been determined by the values of sound guilt/ innocence judgments. According to this approach, a guilty plea is a valid substitute for any constitutionally tainted factfinding process. Thus, if the constitutional defect goes only to evidence, the guilty plea permits a valid conclusion of guilt untainted by the defect. However, under the guilt/innocence approach, a guilty plea would not necessarily extinguish constitutional objections that go to the very validity of bringing a defendant to trial.16s Thus in Menna the Court held cognizable claims that would prevent prosecution of the defendant at all. More recently, Justice White, concurring in Henderson v. Mor$\mathrm{gan},{ }^{109}$ was joined by Justices Blackmun, Stewart, and Powell in forcefully reiterating the position that guilt/innocence values control the guilty plea cases. Indeed, White in Morgan went to great lengths to

165. The grand jury may also be viewed as an institution that sets the agenda for the criminal process by deciding whether and for what crime a defendant should be tried cren after a threshold determination of probable cause. Of course, this theoretical function of the grand jury is usually performed by the prosecutor.

166. 423 U.S. 61 (1975) (per curiam).

167. Blackledge v. Perry, 417 U.S. 21, 35-37 (1974) (Rehnquist, J., dissenting).

168. 423 U.S. at 62 n.?. The per curiam opinion adopts Justice White's view expressed in his dissent in Lefkowitz v. Newsome, 420 U.S. 283, 294 (1975) (White, J., dissenting). For a discussion of this view, see Alschuler, The Supreme Court, The Defense Attorney, and the Guilty Plea, 47 U. CoLo. L. REv. 1, 30-37 (1975).

169. 426 U.S. $637,647-52$ (1.976) (White, J., concurring). 
reconcile even North Carolina $v$. Alford ${ }^{170}$ to such a theory-a case which held that a guilty plea need not be vacated merely because the defendant had consistently protested his innocence. ${ }^{171}$ The result is far more explicable in terms of efficiency and waiver. Therefore, the efforts of Justice White and his three brethren to reconcile Alford to the guilt/innocence rationale signal the theory's dominant rhetorical position in guilty plea cases.

\section{The Recent Habeas Corpus Decisions}

These tensions in the Burger Court's general approach to the criminal process have resurfaced in the recent cases which have attacked federal collateral relief for state prisoners. The exception to Fay wrought by the Brady Trilogy was an indirect attack on habeas corpus; it was not until 1976 that the Supreme Court directly confronted the appropriate scope of federal post-conviction relief for state prisoners outside the guilty plea context. In the last two Terms the Court has handed down four opinions that have struck at the letter and spirit of Fay and the redundancy that it has fostered. ${ }^{172}$ In launching the attack, the Court has relied upon the same theories noted in the guilty plea cases: "waiver" and "guilt/innocence reliability."

The primary elements of Fay $v$. Noia had been: (a) a high waiver standard requiring deliberate bypass of state remedies before a federal right is deemed waived; (b) no automatic attribution of counsel's acts or omissions to the client; (c) no estoppel of federal court consideration of a claim by virtue of state adjudication. All three elements of Fay were eroded by three decisions of the Court decided during the 1975 Term: Estelle v. Williams, ${ }^{173}$ Francis $v$. Henderson, ${ }^{17 t}$ and Stone $v$. Powell. ${ }^{175}$ Fay itself was not confronted openly in any of these cases,

170. 400 U.S. $25(1970)$.

171. Alford is based on the fact that the defendant could intelligently have concluded that, whether he beliered himself to be innocent and whether he could bring himself to admit guilt or not, the State's case against him was so strong that he would have been convicted anyway. Since such a defendant has every incentive to conclude otherwise, such a decision made after consultation with counsel is riewed as a sufficiently reliable substitute for a jury verdict that a judgment may be entered against the defendant.

426 U.S. at 648 n.l (White, J., concurring).

172. Stonc v. Powell, 428 U.S. 465 (1976); Francis r. Henderson, 425 U.S. 536 (1976); Estelle v. Williams, 495 U.S. 501 (1976). As this article was going to press the Supreme Court handed down the fourth case, Wainwright v. Sykes, 45 U.S.L.W. 4807 (U.S. June 23, 197 7 ), which explicitly limited Fay $v$. Noia. Discussion of the implications of Wainwright has been left to the Epiloguc, pp. 1100-02 infra.

173. 425 U.S. 501 (1976).

174. 425 U.S. 536 (1976).

175. 428 U.S. 465 (1976). 
but the implications for Fay were obvious. Justice Brennan who dissented on Fay grounds in all three cases, challenged the Court's honesty in Francis $v$. Henderson, arguing that the Court intended to do Fay in without ever confronting the case. He wrote: " $I$, for one, do not relish the prospect of being informed several Terms from now that the Court overruled Fay this Term . ..."176 What did these cases decide?

In Estelle v. Williams, the petitioner claimed that his trial was unconstitutional because he was clothed in prison garb. He had been represented by retained counsel in his jury trial for assault with intent to commit murder with malice. Before his trial Williams asked his jailer to permit him to wear his own civilian clothes to trial. ${ }^{177}$ The request was refused. At the trial neither the defendant nor his lawyer objected to the prison garb before the court. Williams was convicted, and the conviction was upheld by the Texas Court of Criminal Appeals. ${ }^{178} \mathrm{He}$ then sought relief via federal habeas corpus. The district court held that trial in prison clothes was a denial of due process, but ruled that the denial of due process had been harmless error in this instance. ${ }^{179}$ The Fifth Circuit reversed, holding that while the evidence that defendant had knifed his landlord was overwhelming and not possibly subject to refutation, the circumstances leading up to the assault were subject to two very different interpretations. The degree of the offense depended upon which of these interpretations would be accepted, a judgment that might be influenced by the jury's general perception of the defendant. Under such circumstances, the Fifth Circuit held, the prison garb was not harmless error. ${ }^{180}$

The Supreme Court reversed. All of the members of the Court agreed that compelling a defendant to stand trial in prison garb constitutes a denial of due process. ${ }^{151}$ However, Chief Justice Burger, for the majority, wrote that the denial of due process occurs only if the defendant is compelled to so dress. ${ }^{15: 2}$ The failure to make a timely objection at trial would negate the element of coercion. ${ }^{183}$ The Chief Justice did not use the language of waiver, but his requirement of

176. 425 U.S. at 547 (Brennan, J., dissenting).

177. 425 U.S. at 502 .

178. IId. at 503 .

179. Id.

180. Williams v. Estelle, 500 F.2d 206, 210-12 (5th Gir. 1974), rev'd, 425 U.S. 501 (1976).

181. 425 U.S. at 504-05; id. at 513 (Powell, J., concurring); id. at 515-16 (Bremman, J., dissenting).

182. Id. at 507-08, 512.

183. Id. at 508-10. 
coercion together with his inference of noncoercion from the failure to object is the functional equivalent of a waiver rule in which a claim or right is deemed waived if not raised or invoked in timely fashion. Addressing the argument that the trial judge should have raised the issue sua sponte, the Chief Justice stressed the importance of the participation of counsel: "Under our adversary system, once a defendant has the assistance of counsel the vast array of trial decisions, strategic and tactical, . . . rests with the accused and his attorney."184 One may agree with the Chief Justice that there are many situations in which it is problematic to impose responsibility for initiative on the trial judge. His role is normally umpireal and he depends upon counsel to bring defects to his attention. But Estelle is not such a case. Trying a defendant in prison garb is the kind of defect that glares up at the trial judge.

Chief Justice Burger's willingness to find forfeiture of a right from counsel's failure to act is also troublesome. In light of the uncontradicted evidence that the defendant had objected to the jailer about the prison clothes, and in light of the fact that the appearance of the defendant in such garb could seriously impair guilt/innocence determinations, one would have thought Estelle to be a case particularly amenable to the rule of Fay: requiring a knowing and intelligent waiver by the defendant himself before barring federal relief. Admittedly such a waiver standard and nonattribution presumption at times may seem unduly generous to defendants-particularly where the only evidence of the defendant's choice is his lawyer's acts at trial and his own post-conviction accounts. Again, however, Estelle is not such a case. There was independent evidence of the defendant's contemporaneous objections to the jailer. It is, thus, an easy case for Fay-one where we need have little doubt that Fay's insistence upon the distinction between counsel and client reflects life not legal logic.

Justice Powell concurred in the opinion of the Court but added a separate opinion in which he was joined by Justice Stewart. That opinion is even more pointed in its implications for Fay. Chief Justice Burger's opinion struck principally at Fay's requirement of an independent choice by the defendant; Justice Powell's opinion threatened to eviscerate the deliberate bypass test. It found "a procedural default" or a "tactical choice" in counsel's failure to raise a "trial-type" right.. 185 Justice Powell's willingness to infer a tactical choice in a most unlikely situation and to draw the inference from silence amounts to an

184. Id. at 512.

185. Id. at 514-15 (Powell, J., concurring). 
overruling of Fay's strict test. This erosion is questionable precisely in cases like Estelle $v$. Williams where there is evidence that the attorney and client should not be treated as one moral unit; there was reason to believe that the client-had he acted-would have acted differently.

In Francis $v$. Henderson, ${ }^{180}$ decided on the same day as Estelle $v$. Williams, the Court ruled that objections to the racial composition of a grand jury that were not made in advance of trial as required by state law could not be raised collaterally on federal habeas corpus. The petitioner Abraham Francis, a 17-year-old black man, was indicted by a grand jury in Louisiana in 1965 for felony-murder. Subsequent to conviction, he raised on habeas a claim that the state had excluded daily wage earners from the grand jury, resulting in exclusion of a disproportionate number of blacks. The district court granted habeas relief, but the Fifth Circuit vacated the order remanding for a determination of whether the exclusion amounted to prejudice. ${ }^{18 i}$ The Supreme Court affirmed in an opinion by Justice Stewart, relying principally on Davis v. United States, ${ }^{1 s s}$ which had denied collateral relief on $\$ 2255$ motions to federal prisoners in similar situations. The reasoning of Davis, reiterated in Francis, was that

[i]f defendants were allowed to flout ... time limitations, ... there would be little incentive to comply with [their] terms .... Strong tactical considerations would militate in favor of delaying the raising of the claim in hopes of an acquittal, with the thought that if those hopes did not materalize, the claim could be used to upset an otherwise valid conviction at a time when reprosecution might well be difficult. ${ }^{189}$

"[C]onsiderations of comity and federalism" required that these important practical interests be respected as much when put forth by the states. ${ }^{100}$

Unlike Estelle v. Williams, which permits an inference that a showing of good cause for the failure to raise the issue at trial might suffice to permit its being raised on habeas corpus, Francis concludes summarily that: "In a collateral attack upon a conviction [the Davis] rule requires ... not only a showing of 'cause' for the defendant's failure to challenge the composition of the grand jury before trial, but

186. 425 U.S. $536(1976)$.

187. Newman v. Henderson, 496 F.2d 896, 898-99 (5th Cir. 1974), rev'd sub nom.

Francis v. Henderson, 425 U.S. 536 (1976).

188. 411 U.S. 233 (1973).

189. Id. at 241 (quoted in Francis v. Henderson, 425 U.S. 536, 540 (1976)).

190. Francis v. Henderson, 425 U.S. 536, 541 (1976). 
also a showing of actual prejudice."101 This requirement should effectively bar grand jury challenges in habeas proceedings, since it is nearly impossible to conceive of a claim that could establish prejudice. ${ }^{192}$

Both Estelle v. Williams and Francis v. Henderson bespeak hostility to the strategy of duplication and relitigation to enforce constitutional mandates. Hostility to that strategy was expressed as well in a different fashion by Stone v. Powell. ${ }^{193}$ While Estelle and Francis considered the preclusive consequences of failure to raise federal constitutional claims at the proper time in state proceedings, Stone v. Powell decided the preclusive consequences of raising claims in the state court. In Stone the Court held that actual litigation and denial of the Fourth Amendment exclusionary claim before the state court would have a res judicata effect in federal habeas corpus provided that the state had afforded the petitioner an opportunity for full and fair litigation of the claim. ${ }^{194}$ The key to Stone is found in footnote 31 of the opinion. ${ }^{195}$ There the Court observed that exclusionary rule claims are disfavored because they frustrate the true aim of the criminal process: conviction of the guilty and acquittal of the innocent. Reversal of a conviction for a Fourth Amendment violation was therefore an inappropriate exercise of habeas corpus jurisdiction.

Stone, by reviving res judicata, directly contradicts the redundancy principles of habeas corpus articulated in Brown $v$. Allen ${ }^{196}$ and strongly reaffirmed in Fay $v$. Noia. ${ }^{197}$ In various contexts, members of the Court have intimated that a res judicata rule might be applied wherever the right asserted does not go to reliability of guilt/innocence

191. Id. at 542 (cmphasis added) (footnote omitted).

192. The prejudice requirement could mean that the petitioner must show a causal relationship between the defect in composition and the decision to indict. This is itself very difficult to demonstrate. Alternatively, the Court could mean to impose an eren stricter test, requiring a showing that the improper grand jury decision had somehow affected the decision to convict at trial. Such a burden would be impossible to meet.

193. 428 U.S. 465 (1976).

194. Id. at $481-82$.

195. Id. at 491 n.31.

The habeas issue in Slone was addressed in the context of the extent of the Fourth Amendment exclusionary rule's application to the states. The Court concluded that the policy of this dule clictated against its application through habeas proceedings after full review by state courts. $I d$. at 493 . The Court's doubts about the value of the exclusionary rule, rather than its views of habeas corpus, may appear to supply the primary motice for decision. But the Court did not disapprove of Mapp v. Ohio; and subsequent cave law, see pp. 1086-1100 infra, indicates that it was probably the guilt/innocence perspective, rather than disdain for the exclusionary rule, that lies at the base of the decision. Sec 428 U.S. at $5 \mathrm{I} 5-25$ (Brennan, J., dissenting).

196. 344 U.S. 443, 458 (1953) (state adjuclication should carry weight in federal court, but it is not res judicala).

197. 372 U.S. $391,421-22$ (1963). 
determinations. Justice Powell has stated that Stone should be extended at least to discriminatory grand jury claims since such claims may be "mooted" by a subsequent error-free trial. ${ }^{108}$ This extension would directly overrule Brown v. Allen. ${ }^{199}$ And in Brewer v. Williams, the Chief Justice, in dissent, argued that Stone should have barred relitigation of the Massiah-type counsel claim in that case. ${ }^{200}$ Justice Powell, who concurred with the Brewer majority that a denial of counsel had occurred, observed in response to the Chief Justice's vituperations that the Stone v. Powell issue had not been presented by either party or litigated below. ${ }^{201}$ Justice Powell noted, however, that some Fifth and Sixth Amendment claims might be appropriate for Stone estoppel. ${ }^{02}$

\section{B. Waiver and Innocence}

In these cases, then, the Court has proceeded along the same distinct lines of analysis in limiting Fay as were developed in the guilty plea cases. Estelle and Francis represent the waiver approach, an approach that is a general attack upon the very idea of redundancy. It is a plea for certainty, finality, and efficiency understood in linear terms. The approach is content-free; it says nothing about the nature of the rights that are to exist or about their relative ordering. The Chief Justice and Justice Rehnquist have spoken most forcefully for this position.

The Court's second line of analysis, the guilt/innocence approach, is represented by Stone. It substitutes for the universal scope of: Fay's solicitude for constitutional rights a preference for rights which are

198. Castaneda v. Partida, 97 S. Ct. 1272, 1287 n.l (1977) (Powell, J., dissenting).

199. 344 U.S. at $452,453$.

200. 97 S. Ct. 1232, 1254 (1977) (Burger, C.J., dissenting). In Brewer the defendant was arrested in Davenport, Iowa, for alleged abduction, molestation, and murder of a tenyear-old girl. At the time of his arrest the defendant had declared his intention not to respond to interrogation until he had consulted with his lawyer in Des Moines, where the trial was to be held. During the trip returning the defendant to Des Moines a police officer elicited incriminating statements from the defendant although he had promised defendant's counsel that no interrogation would take place. The statements were admitted into evidence at trial over the defendant's objection. Id. at 1235-37. On these facts, the Court held that the defendant had not waived his constitutional rights and that the attempt to elicit incriminating statements denied him assistance of counsel. $I d$. at $1240-41,1242$. But it expressly refrained from holding that a defendant's refusal to answer questions before consulting with counsel may never be waived. $I d$. at 1243 .

201. Id. at 1246.47 (Powell, J., concurring).

202. Id. at 1247. Justice Powell noted that the reach of Stone-whether it applies only to claims that "closely parallel claims under the Fourth Amendment" or is felevant to habeas corpus procecdings generally-is a difficult question "which should be resolved only after the implications of such a ruling have been fully explored." Id. 
related to a trial's truth-finding process. Justices Powell, White, Blackmun and Stewart appear most taken with this approach. ${ }^{203}$

Both the linear efficiency objectives of Estelle and Francis and the guilt/innocence focus of Stone $v$. Powell operate as criticisms of Fay' and of the remedial order it created. But these two lines of criticism of the Warren Court's work are neither consistent with one another nor equally coherent. We shall argue in this section that the emphasis upon guilt/innocence rights contains within it the promise of a renewed dialogue on the future of the criminal law-a dialogue with a new substantive agenda. Such a reoriented dialectic will retain the potential to express both the practical constraints and the ideals of the law with respect to criminal justice. However, we shall argue, the same is not true for the waiver approach engendered by the quest for efficiency in Estelle. Such a waiver doctrine is either a sham or is internally incoherent absent remedial choices that this Court is almost certainly unwilling to make. The viability of the dialogue depends upon the capacity of guilt/innocence to be used critically as well as apologetically. Such critical uses of guilt/innocence cannot easily coexist with a case like Estelle $v$. Williams.

\section{The Implications of Waiver}

The underlying premises of Estelle $v$. Williams and Francis $v$. Henderson are apparent in Justice Rehnquist's work in the guilty plea cases. They posit a combative, adversary criminal system with defendant and prosecutor competently representing their respective positions. The judge is viewed as an umpire who must supervise the maintenance of professional norms and correct deficiencies in structure. $\mathrm{He}$ is not an active participant in the truth-finding process. ${ }^{20 . t}$

203. This characterization of the Justices' views should not be taken to mean that they have adopted mutually exclusive positions. Except for Justices Brennan and Marshall, who have dissented in defense of Fay $v$. Noia in all the major cases discussed herein, the other Justices have often joined in their brethren's opinions. For example, Justice Stewart wrote the majority opinion in Francis $v$. Henderson and was joined by Chief Justice Burger and Justice Rehnquist. Burger's opinion in Estelle $v$. Williams was likewise joined by Justices White and Blackmun. One noteworthy exception is Justice White's separate dissent in Stone v. Powell. Justice Stevens's position is as yet unclear. He did not participate in Estelle or Francis, joined the majority in Stone, and wrote a narrow concurrence in Wainwright v. Sykes, 45 U.S.L.W. 4807, 4814 (U.S. June 23, 1977). Thus the rough categorization of the Justices here adopted should be taken as representing tendencies in their thought, rather than well-developed ideologies.

201. See p. 1074 supra. Perhaps the most thoughtful commentator on this model for the judicial process has been Judge Frankel. See Frankel, From Private Fights Toward Public Justice, 51 NX.U. L. REv. 516 (1976); Frankel, The Search for Truth: An Umpireal View, 123 U. PA. L. Rev. 1031 (1975). He is cool to the idea that intervention by the judge can correct defects in the adversary process, since such judicial intrusions 
Crucial to the functioning of this process is the provision of defendant with adequate counsel. ${ }^{205}$ This is made clear by the guilty plea cases that stress that the validity of the plea process depends upon the competence of counsel. ${ }^{206}$ The Chief Justice has taken this position to its logical extreme in the context of criminal trials. Dissenting in Faretta $v$. California, ${ }^{207}$ he argued that defendants do not have a constitutional right to represent themselves.

The theory's emphasis on a dominant position for counsel furthers goals of efficiency and finality. The defense-a counsel/client aggregate-is presumed competent and aware of constitutional rights. Failure to invoke those rights may be deemed deliberate and binding. ${ }^{208}$ Hence, Chief Justice Burger may conclude in Estelle $v$. Williams that failure to object to trial in prison garb binds the defendant. To require the trial court to correct such a defect "would rewrite the duties of trial judges and counsel in our legal system."200

The moral underpinnings of such an approach are grounded in an ideology of individualism. Informed, uncoerced people may choose among the valid alternatives that life places before them. They may act in their own interests and for their own ends, but society may then hold them to their acts and omissions. More importantly, society may validly build an adversary process around the assumption that men will so act. Once counsel is provided, the court may expect the defense to exercise autonomous choices and to be bound by those choices.

On a deeper level, there is an inconsistency between the theory's notions of individualism and the role of counsel. A criminal justice system that posits and protects a defendant's autonomy creates a serious tension if it insists that a defendant be counseled against his will or if it permits counsel's acts to bind the defendant. The de-

generally proceed from "Olympian ignorance" producing "partial or skewed insights" and result in "occasional, unexpected, sporadic, unprogrammed, and unduly dramatic" interventions "likely to have a disproportionate and distorting impact." Id. at 1042-43. Yet Judge Frankel recognizes that the laissez-faire assumptions of "individualistic warfare before a passive tribunal" on which the adversary system is based fail to give "sufficient assurance of just results." Frankel, From Privale Fights Toward Public Justice, supra at 524 .

205. See Wainwright v. Sykes, 45 U.S.L.W. 4807, 4813 (U.S. Junc 23, 1977) (Burger, C.J., concurring); Geders v. United States, 425 U.S. 80, $88-89$ (1976) (Burger, C.J.) (quoting Powell v. Alabama, 287 U.S. 45, 68-69 (1932)).

206. E.g., Tollett v. Henderson, 411 U.S. 258 (1973); McMann v. Richardson, 397 U.S. $759(1970)$.

207. 422 U.S. 806, 836 (1975) (Burger, C.J., dissenting).

208. See Henderson v. Kibbe, 97 S. Ct. 1730, 1738 (1977) (Burger, J., concurring in the judgment).

209. 425 U.S. at 512. 
pendence implicit in the counsel/client relationship belies the presupposition of autonomy which informs the relationship of the defense to the court. This tension can be ignored only by viewing counsel-client as the smallest unit in the criminal process.

It is important to see the implication of a waiver theory of representation for Fay $v$. Noia. Since the defense unit is presumed to make autonomous choices, collateral relief may be curtailed where the defense has forgone an opportunity to raise the claim. Just as the tactical choice of pleading guilty can extinguish antecedent claims that would have been raised at trial, the tactical choice of not objecting to trial in prison garb is similarly binding. Habeas corpus is left largely to ensure that the defendant was able to make autonomous choices, i.e., that he had competent counsel. As such, its function is not necessarily to redo the system's work; it is rather to ensure that the requisites of the system were present. While under Fay the federal court would have litigated the underlying right, under Estelle $v$. Williams and the Brady Trilogy the question must be phrased as one of the adequacy of the forum or of the lawyer. ${ }^{210}$

In order to preserve the moral credibility of an unforgiving waiver rule furthering efficiency, the stress on competent counsel is natural and necessary. However, in stressing competent counsel, the Court provides a blueprint for attacks upon the process generating convictions. The increase in such counsel claims is not the product of merely tactical choices by defendants. It is the result of an altered perspective on the same events. It is the structural perspective on defective process.

Claims of ineffective assistance could be limited by refusing to disaggregate the defense unit. Holding a defendant to his attorney's choices may be defended on two grounds. First, one might attribute the adverse consequences because the client has chosen his agent and should be bound by that choice. Of course, this reason looks extremely weak in the criminal context where many clients do not choose their attorneys and those that do, often do so on less than adequate information to make a reasonable choice. Second, one might posit that the

210. Cf. Blackledge v. Allison, 97 S. Ct. 1621, 1632 (1977); id. at 1634-35 (Powell, J., concurring). In Allison, the Court affirmed the Fourth Circuit's order for a new evidentiary hearing, stressing the inadequacies of North Carolina's procedures at the time the plea was taken. The Court intimated that under the more adequate procedures now in force, evidentiary hearings would be needed "only in the most extraordinary circumstances." Id. at 1632 n.19.

The waiver theory's focus on structure essentially eliminates the independent nature of the federal forum under Fay. Federal courts do not relitigate; rather they hear claims that the state forum was in some manner inadequate. This role for habeas corpus was defended fourteen years ago by Professor Bator. See generally Bator, supra note 58 . 


\section{Dialectical Federalism: Habeas Corpus and the Court}

acts of the attorney will in fact reflect the will of the client, or at least what the will of a suitably informed and comprehending client would have been under the circumstances. This view is troublesome not only because of the inevitable failings of men and institutions, ${ }^{211}$ but also because there are often structural and systemic deviations from the normative models for court and counsel. That is, there are circumstances in which the self-interest of the attorney may be expected to run counter to the interests of the client, inviting behavior inconsistent with professional standards. These situations in which the interests of attorney and client diverge arise in three broad categories of cases: where the attorney is constrained by his role in an organization, where he is constrained by the characteristics of a market in which he acts, and where he is constrained by "extraneous" social or political pressures.

The first class of cases involves situations in which the attorney acts within an organizational structure-such as a legal aid bureau or public defender office. The organization works subject to resource constraints ${ }^{212}$ and the need to maintain ongoing working relationships with prosecutors and judges. ${ }^{213}$ These constraints may set rather severe limits on defense strategies and tactics. The lack of resources may lead to high caseloads for individual attorneys which in turn may necessitate pleading guilty a high percentage of clients, watching some who are incarcerated remain in jail for longer periods of time, or limiting time spent on investigation and defense preparation. Working conditions and inadequate compensation also produce a high turnover of attorneys, which hinders the development of a corps of experienced and well-trained counsel. ${ }^{214}$

211. A study of the assigned counsel representation system in Virginia found that the Supreme Court of Appeals affirmed $40 \%$ of the appealed convictions without considering constitutional issues because of the failure to make appropriate trial objections. Board of Governors Crim. L. Section of Va. St. B., I Study of the Defense of Indigents in Virginia (1971) (refcricd to in Benner, Tokenism and the American Indigent: Some Perspectives on Defense Services, 12 Aм. Crim. L. REv. 667, 680 (1975)).

212. See Bazelon, supra note 119 , at 814-16.

213. See Wice \& Suwak, Current Realities of Public Defender Programs: A National Survey and Analysis, 10 Cmim. L. BLle. 161, 173-77 (1974).

On occasion the organizational structure of the public defender's office may prove a source of power for protecting defendants. It has been reported that some offices have employed a "defendant's strike" to influence the charging and sentencing decisions of judges and prosecutors. Sec Alschuler, The Defense Attorney's Role in Plea Bargaining, 84 YAL.E L.J. 1179, 1249-51 (1975). By demanding trials for some or all of their clients who would normally plead guilty, public defenders can turn the massive caseload into a potent weapon. This potential has seldom been realized and raises serious questions of professional ethics.

214. See Benner, supra note 211 , at $681-84$. 
The second set of constraints, market conditions, may create divergences between the interests of privately retained or state-appointed counsel and their clients. The market constraints are most clear with respect to guilty pleas. Many lawyers depend upon a high level of low-fee cases, which can be practicably attained only by pleading almost all clients guilty. ${ }^{215}$ Appointed counsel may face high opportunity costs with little potential for future gains in prestige or number of clients. ${ }^{216}$ The uncompensated defense counsel in Francis $v$. Henderson is a prime example. According to Justice Brennan's dissent, he "took essentially no action with respect to petitioner's defense" in the pretrial stage and made only rudimentary motions at trial. ${ }^{217}$ Yet counsel's acts were found by the state court to be within the range of acceptable competence. ${ }^{218}$ Thus, there is sufficient play in the system to permit counsel to present a minimal defense when his interests do not coincide with those of his client.

The third category of cases in which conflicting interest may arise is more diffuse. There are various defenses and strategies available to a defense lawyer that may offend attitudes of the court or community in which he practices. Insofar as the court or community has not accepted the litigative strategy there will be risks of anything from mild disfavor to violence awaiting an attorney who pursues the forbidden course.

Until recently, perhaps the most important and common situation of this sort has involved the claim of racial discrimination in the composition of petit juries and grand juries. In the South and parts of the rest of the nation-and especially in small counties-an attorney who challenged jury composition was understood to be challenging the community's way of life. The Fifth Circuit, in holding that federal courts should be especially receptive to such claims on habeas corpus, explicitly pointed out the constraints upon lawyers with respect to such claims. ${ }^{210}$ In Tollett $v$. Henderson and in Francis $v$. Henderson, the Supreme Court seemed totally oblivious to such disincentives. In-

215. See Alschuler, supra note 213, at 1181-1206; Bazelon, supra note 119, at 812-13; Benner, supra note 211 , at 684 .

216. See generally Alschuler, supra note 213 , at $1256-70$.

217. 425 U.S. 536,554 (Brennan, J., dissenting).

218. Id. at 555 .

219. See Whitus v. Balkcom, 333 F.2d 496, 505-09 (5th Cir.), cert. denied, 379 U.S. 931 (1964); United States ex rel. Goldsby v. Harpole, 263 F.2d 71, 82-83 (5th Cir.), cert. denied, 361 U.S. 850 (1959). By 1973, circumstances and the court's personnel had changed. In Winter v. Cook, 489 F.2d 174,178 (5th Cir. 1979) (en banc), the court announced that it did "not consider breach of trust by counsel to be so prevalent in any jurisdiction of this circuit that this court should, in the absence of proof, place all or even some lawyers in this circuit under the cloud of such an accusation." 
deed, in Tollett Justice Rehnquist pointed to the general failure of local counsel to raise such claims as evidence that Tollet's attorney did not provide ineffective assistance in failing to raise it. ${ }^{220}$ Thus Tollett is a perfect instance of a failure to take account of systemic disincentives to proper attorney behavior. The Court focused on one attorney's conduct and the norm in the legal community; it did not examine the systemic determinants of the norm.

Given these examples of likely systemic divergence between the interests of defendants and their counsel, an attribution theory looks suspect. ${ }^{221}$ Recognition of this divergence puts the waiver theory in a remedial dilemma. While honesty demands that reviewing courts scrutinize the client/counsel relationship, such scrutiny implicates substantial redundancy and greater intrusion into the state criminal system.

Closer scrutiny of counsel could take place in two ways: greater solicitude for ineffective assistance of counsel claims or direct supervision or control of state processes once they have proven unreliable. The first possibility has in fact developed to some extent after the Supreme Court's dictum in MICMann v. Richardson.222 The adoption by most jurisdictions of the reasonable competence standard will increase the number of ineffective assistance claims. Redundancy may thus return with a vengeance, frustrating the very efficiency and finality goals the waiver theory purports to further. This transformation of claims alleging deprivations of constitutional rights into claims alleging ineffective assistance will produce intrusive inquiries by federal district courts into state provision and control of counsel. ${ }^{223}$

220. 411 U.S. 258, 268.69 (1973).

221. This is not to suggest that cach of these distortions may be easily corrected or should be corrected. It may be substantially easier to require a certain level of preparation on the part of public defenders by regulating cascload than to guarantee private criminal attorneys a particular yearly income in order to alleriate "cop-out" pressures. 229. 397 U.S. $759,770-71$ (1970).

223. Analysis of Estelle v. Williams, 425 U.S. 501 (1976), and Francis v. Henderson, 125 U.S. 536 (1976), makes clear the intrusiveness of this reoriented inquiry. In Estelle, a man is tried in prison clothes. He says he clid not want to be so tried and there is contemporaneous evidence indicating that this claim is not simply a post-hoc creation of an idle, imprisoned mind. We are aware, as sensible people, that neither judge nor defense counsel would have permitted Williams to show up for trial wearing nothing but a jockstrap. Now what accounts for defense counsel and judge permitting him to wear clothing which is legally distinguishable from the jockstrap primarily in its presumptive capacity to prejudice a defendant? Under Fay we need not answer this intrusive and insulting question. We need attribute neither improper motive nor incapacity to judge or counsel (though we may have our own ideas about them). Since there is no "deliberate bypass," unless the state can offer much more than appears in opinions or briefs, the road to federal consideration on habeas is open, and the only questions will relate to what happened, not why. Now consider a serious inquiry based 
Second, the inquiries spawned by McMann may be intrusive in their remedial implications. Collateral review may be an inefficient method of attacking problems once we are certain of the solutions to be achieved. If spending ten minutes with one's client constitutes ineffective assistance and public defender resources permit no greater time expenditure, then habeas corpus relief by itself will not remedy the situation. Either habeas corpus will initiate a dialogue as to solutions, or a solution, once in hand, may be imposed. A federal court faced with state systemic deficiencies may force reform by way of a "structural" injunction.224 Indeed, a recent Fifth Circuit decision adopted such a remedy in the face of local resistance to implementation of the right to counsel guaranteed by Argersinger $v$. Hamlin.225 But this alternative appears diametrically opposed to the Court's current hostile approach to equity as evidenced by O'Shea $v$. Littleton ${ }^{220}$

on the rule of Eslelle. Presumably, Williams may offer to show that he was denied effective assistance of counsel. A critical inquiry will relate to what William's attorncy thought he was doing in failing to object to prison garb. The costs of such an inquiry are substantial in terms of the ethics of adrocacy. See Alschuler, supra note 168, at 43-41. In all "effective assistance of counsel" cases candor will lead the attorney either to impeach his own professional competence or to help insulate a conviction lie had been employed to prevent. Certainly so long as one can be certain that self-interest will not play a part in the account, counsel should be permitted to assert his effectiveness when the former client has initiated the inquiry. But is it wise to place lawyers in a position where their own self-interest is insistently employed against their former clients?

In Francis $v$. Henderson the story is similar. After the ruling in Francis, the habeas petition must be recast to allege "cause" for the failure to raise the claim at the appropriate time. Again, the petitioner is likely to frame the issuc as one of effective assistance of counscl. How effective is the assistance of counsel which does not raise a viable discrimination claim in the decp South in 1965? Experienced civil rights lawyers in many Southern counties at that time found that reluctance to truly integrate the jury system was so deep that obviously guilty felons would often be permitted to go free rather than reconstitute the system so as to come up with a valid indictment and conviction. To find effective assistance on the basis that a lawyer's failure to raise a discriminatory jury selection claim was "tactical" is not entirely implausible, but in Louisiana in 1965 it is far more likely that the attorney either feared or shared community prejudices that make such claims unpopular, or that he simply was negligent in failing to make the claim. An unpleasant and potentially insulting inquiry is aroided only if we are willing to presume that counsel's choice is tactical. Justice Brennan's dissent in Francis is overpowering on the facts in suggesting that, if nothing else, counsel's actions do not permit an inference that a conscious decision occurred in the casc. To reach this conclusion, Justice Brennan had to undertake a critical analysis of counsel's actions and nonactions. See 425 U.S. at 554 (Brennan, J., dissenting).

224. See $\mathrm{O}$. Fiss, The Civil Rights Injunction, supra note 12, at 10-11.

225. See Tucker v. City of Montgomery, 410 F. Supp. 494, 506-09 (M.D. Ala. 1976) (three-judge court). But see Gardner v. Luckey, 500 F.2d 712 (5th Cir. 1974), cert. denied, 423 U.S. 841 (1975); note 226 infra.

226. 414 U.S. 488 (1974).

The unwillingness of the Warren Court to expand equity to reform state criminal processes, see pp. 1038-41 supra, is also apparent in the Burger Court. In O'Shea the judge and other court personnel were alleged to have engaged in racially discriminatory acts of bail setting and sentencing. These practices were alleged to have been carried out in order to deter the plaintiff class from engaging in civil rights activities. Id. at 491-92. 


\title{
Dialectical Federalism: Habeas Corpus and the Court
}

\author{
and Rizzo v. Goode. ${ }^{227}$
}

The waiver approach, therefore, faces severe problems in serving as a coherent perspective around which to reorient a dialogue about the criminal law. Such a dialogue might occur with respect to the moral bases of attribution in the counsel/client relationship. That issue is deeply intertwined with the contradictions in the attempt to preserve the defendant's autonomy while protecting the adversary process.

Justice White's opinion put forth overlapping reasons for dismissal of the suit. First, plaintiffs had failed to satisfy Article III case and controversy requirements. Since plaintiffs were not attacking any criminal statutes, the likelihood of their illegal arrest, prosecution or sentencing was held to be wholly conjectural since the Court assumed that plaintiffs "will conduct their activities within the law and so avoid prosecution and conviction" by the allegedly unconstitutional practices. Id. at 497 .

Even assuming that plaintiffs had satisfied Article III requirements, White invoked Younger v. Harris, 401 U.S. 37 (1971), and firmly closed the door on equitable oversight of state administration of justice. An injunction under the circumstances would constitute

nothing less than an ongoing fecleral audit of state criminal proceedings which would indirectly accomplish the kind of interference that Younger v. Harris . . . and related cases sought to prevent.

A federal court should not intervene to establish the basis for future intervention that would be so intrusive and unworkable. . .

Id. at 500 .

White's extension of Younger is misplaced-or, rather, it is one of sereral attempts to build from Younger a states' rights jurisprudence that goes far beyond the policies and facts of that case. In $O^{\prime} S h e a$ the claim of plaintiffs is more than adequate to explain why and how the state courts in question cannot be expected to do their duty under Article VI. The state court judges and prosecutors are the persons whose conduct is at issue; they are themselies the targets of the reform sought. They cannot, therefore, as in Younger, be presumed to carry out their duties conscientiously. O'Shea thus represents a type of claim, similar to claims of bad faith prosecution and harassment, that merits cxception to Younger. Cf. Juidice v. Vail, 97 S. Ct. 1211, 1219-20 (1977) (Stevens, J., concurring in the judgment) (where plaintiffs challenge constitutionality of state procedures, those procedures cannot themselves provide an adequate remedy so as to warrant Younger abstention).

A Fifth Circuit decision indicates the preemptive effect $O$ 'Shea will have on claims brought to compel states to provide more adequate counsel services. In Gardner v. Luckey, 500 F.2d 712, 715 (5th Cir. 1974), cert. denied, 423 U.S. 841 (1975), the court affirmed dismissal, on O'Shea grounds, of a suit requesting an injunction ordering the public defender's office to mect minimum constitutional standards of effectiveness.

227. 423 U.S. 362 (1976).

In Rizzo, the Burger Court made clear that O'Shea goes beyond prospective interference with prosecutors and judges. Faced with an action to correct allegedly pervasive practices of police misconduct in Philadelphia, the Court again stressed that allegations of hypothetical future injury were insufficient to satisfy the Article III case or controvery requirement. $I d$, at $371-73$. The Court also held that the district court's injunction, which required the police department to adopt civilian complaint procedures, violated principles of federalism. Id. at 377-80. Rizzo has, thus, reinforced $O^{\prime} S h e a$ as to the shape of equity. It has also made clear that the stringency of $O$ 'Shea is not simply a product of caution in tampering directly with judges, but is likely to extend to all facets of the criminal process. For a notable exception, see Gerstein v. Pugh, 420 U.S. 103 (1975) (permitting equitable relief in reform of state's pretrial detention procedures).

The evisceration of federal equity power continued this Term. For two examples, overruling federal intervention into state civil proceedings, see Juidice v. Vail, $97 \mathrm{~S}$. Ct. 1211 (1977), and Trainor v. Hernandez, 97 S. Ct. 1911 (1977). 
However, a focus upon that problem is likely to produce an intrusive federal role in the criminal law.

Chief Justice Burger and Justice Rehnquist's strong desire for finality and efficiency in the criminal process is empty without the identification of values which we wish to pursue efficiently. If those values are autonomy and individualism we must be prepared to inquire deeply into counsel provision systems either by federal imposition of a remedy from above or through the dialectical remedy of habeas corpus. To eliminate readjudication of rights without taking seriously other means of quality control is not simply to relegate authority to the states, but purely and simply to lie about the legal and moral foundations of the criminal process.

\section{The Implications of Guilt/Innocence}

\section{a. The Protection of Innocence}

Stone $v$. Powell viewed the central function of habeas corpus as protection of innocent defendants from unconstitutional denials of their liberty. ${ }^{298}$ This premise appears to be based upon the idea that the remedial form-habeas corpus-has a substantive integrity. The Court seems to be saying that habeas corpus protects innocence, while other constitutional values are protected by other remedial devices. Much of the opinion in Stone v. Powell is designed to argue that Fourth Amendment values can be adequately protected in other ways -primarily through direct review and state court enforcement of the Mapp doctrine. ${ }^{229}$

The core idea of Stone, that habeas corpus should primarily protect innocence, is explicitly stated in footnote 31 of the opinion. There Justice Powell wrote: "Resort to habeas corpus, especially for purposes other than to assure that no innocent person suffers an unconstitutional loss of liberty, results in serious intrusions on values important to our system of government." ${ }^{230}$ Justice Powell had advocated such a perspective on habeas corpus for some time prior to Stone. In Schneckloth $v$. Bustamonte he wrote in a concurring opinion:

That federal courts would actually redetermine constitutional claims bearing no relation to the prisoner's innocence with the

228. 428 U.S. 465,491 n.31 (1976).

229. See $i d$. at $486-89,493-95$.

230. Id. at 491 n.31. 
possibility of releasing him from custody if [a] search is held unlawful not only defeats our societal interest in a rational legal system but serves no compensating ends of personal justice. ${ }^{231}$

This perspective on habeas corpus should not be understood, however, as a narrow or technical limitation upon the scope of a remedy. We have argued throughout this article that habeas corpus is, and is understood to be, the primary federal remedy for errors and deficiencies in the criminal process. Furthermore, it is a major vehicle for disciplined articulation and refinement of rights. To limit habeas corpus to rights which bear a particular kind of relationship to innocence, in the absence of expansion of other remedies, is, thus, to establish a hierarchy of constitutional rights for purposes both of enforcement and of substantive articulation. The existence of such a hierarchy will channel the cascade of prisoner petitions in new directions; those petitions will articulate innocence-relevant claims in old and new ways. This channel will deepen as state and lower federal courts consider such claims and rule on novel innocence-relevant rights rather than upon rights which are older, more established, but less closely related to these hierarchically superior values.

This new channel for constitutional relief thus may be deepened and widened until the guilt/innocence theory (which in Stone, read narrowly, forms only remedial contours) serves as the principal doctrine for restricting existing rights and creating new ones. Surely, such a possibility has not escaped the attention of Justice Powell and some of his brethren. ${ }^{232}$ For example, the decision in Stone may be seen as but one manifestation of the Court's dissatisfaction with Mapp and Miranda. While the precise rule of Mapp is reaffirmed in Stone, ${ }^{233}$ in other areas the applications of the exclusionary rule have been limited. ${ }^{234}$ These limitations proceed from a general skepticism about indirect enforcement of the admittedly important values underlying

231. 412 U.S. 218, 258 (1973) (Powell, J., concurring), See Lefkowitz v. Newsome, 420 U.S. 283, 303 (1975) (Powell, J., dissenting) ("The historic and honored purpose of luabeas corpus, and indeed its only justification, is to provide the added assurance to a free society that no innocent person will suffer an unconstitutional deprivation of liberty.") This view, stated in the context of Fourth Amendment claims, can be traced at least to Justice Black's dissent in Kaufman v. United States, 394 U.S. 217, 231 (1969).

232. See Freeman v. Zahradnick, 97 S. Ct. 1150, 1152 (1977) (Stewart, J., dissenting from denial of writ of certiorari); pp. $1098-99$ infra.

233. 428 U.S. at $482-83$.

234. See, e.g., United States v. Calandra, 414 U.S. 338 (1974) (grand jury witness may not invoke exclusionary rule to avoid answering questions based on evidence obtained in violation of Fourth Amendment); Harris v. New Iork, 401 U.S. 222 (1971) (illegally seized evidence can be used to impeach defendant). 
$M a p p,{ }^{235}$ enforcement which permits the guilty to go free. Thus, it seems reasonable to read Stone not only as an indication of the remedial implications of guilt/innocence values but also as a step in the creation of a constitutional jurisprudence in which guilt/innocence is the critical value in the criminal law.

Both on the practical remedial level and on this theoretical plane, however, it is not clear from the cryptic footnote 31 what kind of relationship to innocence is demanded of a right before it may be enforced through habeas corpus. Nor is it clear what, if any, innocenceirrelevant rights may still be enforced collaterally. Although the Court has yet to speak to these questions there are indications of direction both from the guilty plea cases and from dicta in recent opinions.

\section{b. Categorical Versus Individual Focus on Innocence-Relevance}

In Stone the purpose of the redundancy of habeas corpus was said to be the assurance "that no innocent person suffers an unconstitutional loss of liberty." ${ }^{236}$ The estoppel rule was invoked with respect to Fourth Amendment claims on the ground that they do not, as a rule, further sound guilt/innocence judgments. ${ }^{237}$ Are we then to understand Stone to require only that the right in question be positively correlated with sound guilt/innocence judgments? Or are we to understand Stone to require that the petitioner assert a plausible claim of innocence associated with the denial of a constitutional right? ${ }^{23 s}$ In Stone the Court did not consider these questions since the case entailed a right whose enforcement would obstruct sound guilt/innocence judgments. Therefore, the defendant could claim neither that denial of the right hurt guilt/innocence determinations in general nor his in particular.

There are some indications that Justice Powell, as the dominant spokesman for guilt/innocence values, intends to pursue a discriminating, categorical parsing of rights rather than a focus upon individual guilt or innocence. In Brewer $v$. Williams ${ }^{239}$ the Court reversed a state conviction on Massiah-type grounds despite the defendant's clear guilt. The Chief Justice in dissent argued that Stone should have been ap-

235. See United States v. Calandra, 414 U.S. 338, $351-52$ (1974). The best summary of the case against the exclusionary rule remains Chief Justice Burger's dissent in Bivens v. Six Unknown Named Agents, 403 U.S. 388, 411 (1971) (Burger, C.J., dissenting).

236. 428 U.S. at 491 n.31 (emphasis added).

237. See id. at $489-91$.

238. Judge Friendly apparently favors the "individualistic" approach. See Friendly, supra note 81 , at 160 .

239. 97 S. Ct. 1232 (1977). 
plied. He pointed out that the evidence obtained in this case by virtue of the police conduct held unconstitutional was independently valid and probative of guilt. ${ }^{240}$ Justice Powell concurred specially and declined to consider Stone because it had been decided after the lower court decisions in Brewer and the issue had not been briefed or adequately argued. However, in an obviously significant passage, Justice Powell wrote:

Many Fifth and Sixth Amendment claims arise in the context of challenges to the fairness of a trial or to the integrity of the factfinding process. ... [W] hether the rationale of Stone should be applied to those Fifth and Sixth Amendment claims or classes of claims that more closely parallel claims under the Fourth Amendment is a question as to which I intimate no view, and which should be resolved only after the implications of such a ruling have been fully explored. ${ }^{2 * 1}$

Justice Powell's concerns are here phrased primarily in terms of the characteristic ways in which the rights in question operate rather than in terms of the certainty of guilt or innocence of the defendant. Elsewhere, Justice Powell has suggested that Stone be applied to all claims of grand jury discrimination since, from a guilt/innocence perspective, a subsequent valid determination of guilt moots the probable cause determination of the grand jury whose composition is attacked. ${ }^{242}$ In short, Justice Porvell seems to be exploring the ways in which particular rights further or obstruct guilt/innocence judgments rather than the actual guilt or innocence of the petitioners.

The divergent implications of the two alternatives can be demonstrated. A case-by-case focus would degenerate into a weaker variant of the constitutional harmless error rule. The Court's focus would almost certainly be upon the particular facts and the weight of the evidence-possibly even considering evidence not free from constitutional defects. The case-by-case focus would be both unlikely to build a constitutional jurisprudence upon guilt/innocence values and unlikely to set guilty men free. The categorical approach would, conversely, concern itself with the systemic relations of rights to guilt/ innocence judgments. It would also entail drawing distinctions be-

210. Id. at 1250-55. It is interesting that the Chief Justice characterizes Miranda as a decision intended to increase reliability of pre-trial statements. $I d$. at 1252 . Under the equality principle of the Warren Court, Miranda was viewed as a broad prophylactic rule to protect persons from abusive and illegal police practices. See Miranda v. Arizona, 384 U.S. 436,444 (1966).

241. $97 \mathrm{~S}$. Ct. at 1247 (Powell, J., concurring).

242. Castaneda v. Partida, 97 S. Ct. 1272, 1287 n.l (1977) (Powell, J., dissenting). 
tween alternative formulations of rights which either do or do not have the requisite connection to guilt/innocence. Rather than be factbound, the categorical approach could precipitate a federal-state dialogue concerning the attributes of structures and processes for guilt/innocence judgments.

Both of these approaches are evident in the majority and dissenting opinions in Manson v. Braithwaite, ${ }^{243}$ a case decided this Term. There the Court, per Justice Blackmun, opted for a "totality of the circumstances" test for evaluating the reliability of a pre-trial identification based on a photograph. ${ }^{24}$ The Court rejected a per se rule applied by the Second Circuit (and favored by Justices Marshall and Brennan in dissent ${ }^{245}$ ) that would have excluded any identification obtained by unnecessarily suggestive procedures. Both the majority and the dissent argued from the premise that unnecessarily suggestive identification procedures impair the reliability of guilt/innocence judgments. Justice Blackmun, however, stated that once an improper procedure has already been used, the evidence should not be rejected if, in the totality of circumstances, it appears to be reliable. 240 The dissenters asserted that the totality standard would sometimes permit juries to consider unreliable evidence and would be a less effective deterrent to inaccurate police identification methods. ${ }^{247}$ The adoption of an ad hoc approach by the majority represents a choice for the individualistic focus. In the future, courts proceeding under it will be engaged in fact determinations specific to the particular case. The adoption of the minority's per se approach, by contrast, would have created a dialogue on appropriate identification procedures by requiring determinations whether the methods were unnecessarily suggestive. ${ }^{248}$

The case-by-case focus may not always prevail. In Braithwaite itself, Justice Blackmun acknowledged the force of the dissent's position. He treated the disagreement as an honest difference about how best to implement a shared value. Particularly in cases involving the right to counsel, the Court continues to show a willingness to adopt broad

243. 45 U.S.L.W. 4681 (U.S. June 16, 1977).

244. Id. at 4684-85.

245. Id. at 4688-89 (Marshall J., dissenting).

246. Id. at 4685 .

247. Id. at 4688-89 (Marshall, J., dissenting).

248. An underlying tension pervades the opinion. The dissent claims that the majority's rule permits evidence of the defendant's guilt to influence the determination of the reliability of the identification. Id. at 4689 (Marshall, J., dissenting). The majority opinion denies this, $i d$. at 4686 , and Justice Stevens concurs to emphasize the point. $I d$. (Stevens, J., concurring). 
prophylactic rules-a willingness that may be attributable to the fact that counsel rights are implicated in both the waiver and guilt/innocence theories. For example, in Geders $v$. United States ${ }^{249}$ the trial court had ordered at the close of the day's proceedings that a defendant, whose cross-examination was postponed until the next day, not communicate with his counsel overnight. The Court, per Chief Justice Burger, held that the order violated the defendant's Sixth Amendment right to assistance of counsel and reversed the conviction. The Court did not mention the effect that such an order might have had on the guilt/innocence determination, although the court of appeals below had affirmed the conviction on the ground that the defendant had not claimed prejudice resulting from the order. ${ }^{250}$ The Court apparently thought that any interference with assistance of counsel is, in the concurring opinion's words, "inherently suspect." 251

There is, of course, no reason to expect that all issues will be treated in the same way: either with an individual guilt/innocence approach or with an eye to systemic impact on guilt/innocence judgments. Surely it is sensible to expect certain rights of a structural charactercounsel, attributes of the tribunal-to be treated systemically more frequently than those which go to sufficiency of the evidence.

\section{c. Truth-Furthering, Truth-Obstructing, and Truth-Neutral Rights}

The preeminence afforded guilt/innocence values in Stone will require a functional analysis of rights and their consequences. The remedial and substantive implications of rights will depend upon whether they are understood to further accurate guilt/innocence determinations, to obstruct such judgments or to be neutral with respect to them. This functional judgment entails a serious risk of impoverishment of the symbolic qualities of the rights. For example, part of the evocative quality of a right such as the privilege against self-incrimination is its capacity to resonate simultaneously with interests in personal autonomy, limited government, fair (in the sense of balanced) process, and accurate guilt/innocence determinations. The power of the right inheres in its capacity to evoke a broad range of potential applications even as it is applied in only a single instance.

249. 425 U.S. 80 (1976).

250. Id. at $85-86$.

251. Id. at 93 (Marshall, J., concurring).

The Ninth Circuit has recognized the Supreme Court's prophylactic approach to the right to counsel. In Cooper v. Fitzharris, summarized in 21 CrIM. L. REP. (BNA) 2127 (9th Cir. Apr. 11, 1977), the court held that a harmless error rule was inapplicable to claims of ineffective assistance of counsel. 
The tendency to understand a right entirely in functional terms also represents a transition from the discourse of rights to that of interests. By reducing the right's justification to its functional utility, it is almost inevitable that one will engage in a.. cost-benefit analysis, an analysis which is inconsistent with the very idea of rights. ${ }^{252}$ Thus the Court in pursuing the theme of guilt/innocence must beware lest a dominant value become an exclusive one; lest a functional inquiry into a right's consequences for accuracy crystallize a functionalist reduction of the right's content. Justice Brennan, in his dissent in Stone, objected to the Court's reasoning on this ground. ${ }^{253}$

This long-range theoretical concern has short-range practical implications. It is difficult to predict the impact of Stone in many areas precisely because of the resistance of most constitutional rights in their present shape to functionalist reduction. If rights were easily classified along functional lines, we might conclude that Stone holds truthobstructing rights to be unenforceable through habeas corpus; that it strongly implies that truth-furthering rights would be cognizable in habeas corpus; and that it intimates no direct answer concerning the fate of rights which neither further nor obstruct the guilt/innocence inquiry.

Truth-furthering rights are rights that foster sound guilt/innocence determinations with the requisite degree of certainty. The clearest examples of these are the requirements that guilt be based on some evidence ${ }^{25 t}$ and that each element of a crime be proved beyond a rea-

252. See generally Dworkin, Hard Cases, SS HARv. L. REv. 1057 (1975); Wellington, Common Law Rules and Constitutional Double Standards: Some Notes on Adjudication, 83 YaLE L.J. 221 (1973).

253. See 428 U.S. at 523-24 (Brennan, J., dissenting) (citations and footnote omitted) (cmphasis in original):

The Court ... argues that habeas relief for non-"guilt-related" constitutional claims is not mandated because such claims do not affect the "basic justice" of a defendant's detention ... ; this is presumably because the "ultimate goal" of the criminal justice system is "truth and justice." This denigration of constitutional guarantees and constitutionally mandated procedures, relegated by the Court to the status of mere utilitarian tools, must appall citizens taught to expect judicial respect and support for their constitutional rights. Even if punishment of the "guilty" werc society's highest value-and procedural safeguards denigrated to this end-in a constitution that a majority of the members of this Court would prefer, that is not the ordering of priorities under the Constitution forged by the Framers, and this Court's sworn duty is to uphold that Constitution and not to frame its own. The procedural safeguards mandated in the Framers' Constitution are not admonitions to be tolerated only to the extent they serve functional purposes that ensure that the "guilty" are punished and the "innocent" freed; rather, every guarantee enshrined in the Constitution, our basic charter and the guarantor of our most precious liberties, is by it endowed with an independent vitality and value, and this Court is not free to curtail those constitutional guarantees even to punish the most obviously guilty.

254. See Thompson v. City of Louisvilie, 362 U.S. 199 (1960). 
sonable doubt.. ${ }^{25 \bar{s}} \mathrm{~A}$ truth-obstructing rule is best exemplified by the exclusionary rule of Mapp considered in Stone. As Justice Powell wrote in Stone, the evidence sought to be excluded "is typically reliable and often the most probative information bearing on the guilt of the defendant .... Application of [the exclusionary] rule thus deflects the truthfinding process and often frees the guilty." 256 A similar argument can be made for other exclusionary rule claims, particularly claims based on technical violations of Miranda and Massiah. This possibility has received the attention of the Chief Justice and Justice Powell. 257

But most constitutional rights do not fit neatly into the category of truth-furthering or truth-obstructing. For example, rights that prevent prosecution or punishment of the defendant operate regardless of the defendant's guilt or innocence. Claims such as double jeopardy, ${ }^{2 s s}$ denial of speedy trial, ${ }^{250}$ collateral estoppel, ${ }^{260}$ breach of prosecutorial promises, ${ }^{201}$ or grants of immunity simply render determination of the defendant's guilt or innocence irrelevant. These "guilt-irrelevant" rights contrast with the exclusionary rule which merely blocks one avenue of proof but does not alter our normal conception that this defendant, if guilty, should be convicted. The status of guilt-irrelevant rights under the rule of Stone is undetermined. The Court, however, has recognized such claims in habeas in the guilty plea context and after trial. ${ }^{202}$ If such claims continue to be cognizable in habeas corpus, the estoppel rule of Stone will become substantially narrower.

The Court probably will not attempt to force all rights into the tripartite scheme. Rights which this Court considers fundamental may be excepted from Stone without consideration of their impact on a particular guilt/innocence determination. These exceptions may be seen as rights protecting cherished ideals of fair treatment in the criminal process. ${ }^{203}$ However, in light of the Court's new functional

255. See In re Winship, 397 U.S. 358 (1970).

256. See Stone v. Powell, 428 U.S. 465, $489-90$ (1976).

257. See Brewer v. Williams, 97 S. Ct. 1232, 1250-55 (1977) (Burger, C.J., dissenting); id. at 1246.47 \& n.2 (Powell, J., concurring).

258. See Menna v. New York 423 U.S. 61 (1975) (per curiam).

259. See Barker v. Wingo, 407 U.S. 514 (1972).

260. See Ashe v. Swenson, 397 U.S. 436 (1970).

261. See Santobello v. New York, 404 U.S. 257 (1971).

262. See, e.g., Menna v. New York, 423 U.S. 61 (1975) (per curiam) (double jeopardy claim after a guilty plea); Ashe v. Swenson, 397 U.S. 436 (1970) (collateral estoppel after second conviction).

263. See Brewer v. Williams, 97 S. Ct. 1232 (1977) (although defendant's guilt not seriously in doubt, habeas relief granted for failure to exclude evidence obtained in violation of right to assistance of counsel).

The Court has given special treatment to certain rights by holding them subject to a 
approach, it may be more accurate to characterize these rights as categorical judgments about the rights' importance to guilt/innocence determinations. Viewed this way, they become special instances of truth-furthering rights.

These qualifications suggest a more precise reading of the rule of Stone: A claim of a constitutional right is estopped on habeas corpus if and only if (a) it has been litigated in a fair and adequate forum; (b) it does not impair the certainty of our post hoc conclusion that the defendant is guilty; (c) it does not constitute a constitutional right to be free from conviction despite guilt; and (d) it is not a right granted special protection due to its fundamental nature.

Ultimately, many rights resist such categorization altogether. All matters concerned with agenda setting in prosecution for crimes are examples: claims of impropriety in the exercise of prosecutorial discretion or in the composition or acts of grand juries. If the grand jury's only or primary concern were determination of probable cause, its composition might be deemed innocence-relevant and consequently mooted by the subsequent and independently valid guilty plea or verdict of guilt beyond a reasonable doubt. To recognize a grand jury claim collaterally would be to recognize a claim that neither impairs the soundness of the judgment of guilt nor points to values rendering that judgment irrelevant. Alternatively, however, the grand jury may be viewed as the organ which sets the agenda for prosecution and which properly decides, sometimes upon non-guilt-related bases whether to invoke the criminal process. ${ }^{204} \mathrm{~A}$ defect in the composition of the body that makes such choices is not mooted by the finding of guilt. A claim of racial discrimination in the exercise of prosecutorial discretion bears a similar uncertain relation to guilt/innocence judgments. In both cases, the defendant usually cannot claim that he himself has a right to be free from prosecution despite guilt, but only that he would have been more likely to have been granted such a disposition had the deliberative organ been appropriately designed or had it acted properly. The present Court is overtly hostile to such probabilistic formulations of constitutional rights. ${ }^{205}$ Not surprisingly, there-

knowing and intelligent waiver standard. These are rights "which the Constitution guarantees to a criminal defendant in order to preserve a fair trial." Schneckloth v. Bustamonte, 412 U.S. 218, 237 (1973) (footnote omitted) (citing rights to counsel, to confrontation, to a jury trial, to a speedy trial, and against double jeopardy).

264. See Francis v. Henderson, 425 U.S. 536, 557-58 (1976) (Brennan, J., dissenting). An example of agenda setting on a non-guilt related basis might be a decision by $\mathbf{a}$ properly constituted grand jury not to indict marijuana possessors. If an improperly constituted grand jury would indict in the same situation, the defendant would have a claim that could not be mooted by subsequent conviction at trial.

265. See, e.g., Washington v. Davis, 426 U.S. 229 (1976). 
fore, all current indications point to a conclusion that grand jury claims will be subsumed under the rule of Stone.206

Whether grand jury claims ultimately end up within or without the rule of Stone, it is reasonably clear that guilt/innocence values cannot exhaust the subject matter of habeas relief without a drastic impoverishment of the language of rights. A dialogue should continue over the broad range where there are values which render guilt irrelevant; it may disappear or diminish in the narrow range where the guilt/innocence determination is obstructed by recognition of the rights in question; and it will, one hopes, intensify where guilt/innocence values inform the evolution of constitutional rights. It is to this hope that we now turn.

\section{d. A Dialogue on Innocence}

The most disturbing element in the Court's decision in Stone $v$. Powell is the juxtaposition of two footnotes. Footnote 31, with its emphasis upon the necessity to protect innocence through federal habeas corpus, must be set against the language of footnote 35 in the same opinion:

Despite differences in institutional environment and the unsympathetic attitude to federal constitutional claims of some state judges in years past, we are unwilling to assume that there now exists a general lack of appropriate sensitivity to constitutional rights in the trial and appellate courts of the several States. ${ }^{207}$

This assumption-which is supported by no evidence-is made in the specific context of the refusal to enforce $M a p p$ claims through the federal writ. However, it could as easily support a general withdrawal of federal remedies even for those rights which are related to sound guilt/innocence judgments. Footnote 35 is Justice Powell's concession to those ideas which, and those Justices who, would truncate any dialectic or conflict surrounding values in the criminal process in the interests of efficiency, finality, or "Our Federalism."

The particular context of Stone $v$. Powell made it possible to write both of these footnotes-to further the ends of sound guilt/innocence judgments via respect for the autonomy of state institutions and judges. But the substantive guilt/innocence value of footnote 31 will not always cut in that direction. And footnote 31 suggests strongly that

266. See Castaneda v. Partida, 97 S. Ct. 1272, 1287 n.l (1977) (Powell, J., dissenting). 267. 428 U.S. at 493 n.35. 
where innocence is implicated this value should override interests in state autonomy or in efficiency.

If the values expressed in footnote 31 predominate, innocence, in theoretical terms, will become the foundation for rights. In practical terms innocence-relevance will create the habeas petitioner's opportunity for judicial cognizance of his claims. Just as McMann made petitioners transform denials of constitutional rights into ineffective assistance of counsel claims, so the ascendancy of a guilt/innocence rationale will refocus the attention of prisoners upon those elements in their trial which both adversely affected the outcome and have strong connections with the determination of guilt and innocence.

This change in the subject matter of habeas corpus would not threaten redundancy as would the efficiency rationale. Rather, it would reorient the axis of the dialogue. The new subject matterguilt/innocence-is as rich, as vague, as promising, and as problematic as equality. It is the starting point for discussion, not a blueprint for results. As such, it must be elaborated in the context of our varied experiences and perspectives. This elaboration can be achieved through the vehicle of habeas corpus, which implicates the pointed consequences of federal intervention, not the heavy blunt instrument of federally imposed solutions. Already, some of the contours of the dialogue are visible.

Guilt/innocence shares some objects of attention with other value orientations. The importance of adequate representation and of a fair and unbiased forum are not diminished. ${ }^{268}$ However, there are two special and far-reaching concerns which emerge from the guilt/ innocence focus. These are the trustworthiness of a guilty plea wholly apart from its intelligence and voluntariness, and the quality and sufficiency of the evidence.

The first issue implicates the rule of North Carolina $v$. Alford,200 where a plea of guilty was held binding despite the defendant's refusal to admit his guilt. A utopian guilt/innocence perspective upon the guilty plea can only regard Alford an acute embarrassment; ${ }^{270}$ the defendant is neither found guilty nor does he admit guilt. Yet the result in the case furthers intelligible, practical ends. It avoids the potentially inequitable result of forcing precisely those defendants who

268. Professor Bines, supra note 28 , at 933 , has suggested that ineffective assistance of counsel claims in habeas be limited to situations where counsel's acts could have affected the determination of guilt or where counsel was so obviously incompetent that the trial judge should have corrected him.

269. 400 U.S. 25 (1970).

270. See note 171 supra. 
might be innocent but against whom evidence is strong to forgo the advantages of a plea bargain that admittedly guilty defendants could make. It also avoids forcing the defendant who thinks himself innocent to lie to get the advantage of the plea. Nevertheless, it is possible that the practical end served by Alford can be met in other ways.. ${ }^{271}$ It is important to require that the court accepting an Alford plea be aware of the potential conflict with guilt/innocence values that the plea creates. Federal habeas corpus can intensify dialogue on these points through intense scrutiny of Alford plea cases.

More far-reaching is the question of quality and sufficiency of the evidence in cases which do go to trial. Traditionally, evidentiary rules have been matters for state law. The right of confrontation, however, has been developed since Pointer $v$. Texas ${ }^{272}$ in a number of cases which make the interests served by hearsay rules of constitutional significance. ${ }^{273}$ Elaboration of these rights should continue after Stone.

The issue of the sufficiency of the evidence has received particular attention by the Burger Court. In In re Winship the Court constitutionalized the right to a standard of proof beyond a reasonable doubt. ${ }^{274}$ It went further in Mullaney $v$. Wilbur holding that the prosecution must bear the burden of proof as to all factors that affect assessment of the degree of the defendant's culpability. ${ }^{275}$ In Patterson v. New York, ${ }^{2 \pi 0}$ announced this Term, a majority of the Court seriously undermined the practical significance of Mullaney by hold-

271. Alternatives to Alford exist. The Court might require, where the defendant cannot or will not admit that he has in fact committed the acts in question, that a trial occur as to those material elements not admitted. The defendant could be asked to cooperate through waiver of certain rights-perhaps his right to remain silent or possibly a jury trial-in return for a commitment that he would face a maximum sentence no greater than that which would have been imposed upon a plea of guilty. These rights are either unnecessary to, or hinder, the judge's determination that the defendant is in fact guilty. Waiver of them by the defendant leaves him in no worse a position than would the guilty plea he sought to enter. Under this system, the court would satisfy itself as to the factual basis for conviction beyond a reasonable doubt. The defendant would get no less than what he gets under Alford and in a few deserving cases would be found innocent.

272. 380 U.S. 400 (1965).

273. Cases interpreting the confrontation clause of the Sixtl Amendment stress the necessity of ascertaining the reliability of out-of-court statements offered as eviclence. See Mancusi v. Stubbs, 408 U.S. 204, 213 (1972); Dutton v. Evans, 400 U.S. 74, 89 (1970) (plurality opinion); California v. Green, 399 U.S. 149, 161 (1970). This approach also may necessitate denying effect to mechanical application of state evidentiary rules where independent indicia of reliability are present. In Chambers v. Mississippi, 410 U.S. 284 (1973), the Court, per Justice Powell, invalidated a state rule prohibiting the defendant from impeaching his own witness and held that reliable, probative, hearsay evidence favorable to the defendant's case was improperly excluded.

274. 397 U.S. 358 (1970).

275. 421 U.S. 684 (1975).

276. 45 U.S.L.W. 4708 (U.S. June 17, 1977). 
ing that a state has very broad legislative power to designate affirmative defenses and thereby place the burden of proof upon the defendant. But the holding was limited by the express reservation that "there are obviously constitutional limits beyond which the States may not go" in designating affirmative defenses. ${ }^{277}$ Justice Powell wrote a dissent for himself and Justices Brennan and Marshall. Most interestingly, he defended a standard that would circumscribe the ways in which state legislatures could act, preventing them from using a low-visibility technique (burden of proof) to accomplish politically unacceptable substantive choices. ${ }^{278}$ Such a consideration contrasts sharply with the assumptions about state institutions in footnote 35 of Stone. Justice Powell further acknowledged that the majority's standard (whether the mitigating factor is an affirmative defense as a matter of state law) was easier to administer than his own, but he concluded, "[T]his facile test [of the majority] invites tinkering with the procedural safeguards of the presumption of innocence, an invitation to disregard the principles of Winship that I would not extend."279

The formal acknowledgment of the "proof beyond a reasonable doubt" standard and Justice Powell's demand for stringent protection of it are only the beginnings of foreseeable uses of the guilt/innocence criterion. Still more significant utopian innovations are possible. One was suggested this Term by Justice Stewart in Freeman v. Zahradnick. ${ }^{280}$ Dissenting from a denial of certiorari, he wrote:

If, after viewing the evidence in the light most favorable to the State, a federal court determines that no rational trier of fact could have found a defendant guilty beyond a reasonable doubt of the state offense with which he was charged, it is surely arguable that the court must hold, under Winship, that the convicted defendant was denied due process of law. ${ }^{281}$

Justice Stewart recognized that the principle he advocated would constitutionalize the issue of sufficiency of the evidence. More relevant here, he recognized that this rule would expand the scope of redundancy as a corollary to expansion of innocence-relevant rights.

277. Id. at 4711 .

278. Id. at $4716 \mathrm{n} .13$ (Powell, J., dissenting). See generally Underwood, The Thumb on the Scales of Justice: Burdens of Persuasion in Criminal Cases, 86 Y.ALE L.J., Junc, 1977 (forthcoming).

279. 45 U.S.L.W. at 4717 (Powell, J., dissenting).

280. 97 S. Ct. 1150 (1977).

281. Id. at 1151 (Stewart, J., dissenting to denial of writ of certiorari) (citation omitted). 
The approach I suggest would expand the contours of one kind of claim cognizable on federal habeas corpus. But if such an approach is constitutionally required, a federal habeas court asked to determine whether the evidence in a state prosecution was sufficient would be discharging the principal function underlying its jurisdiction-determining whether a defendant's custody is in violation of federal constitutional law. And the question whether a defendant has been convicted without sufficient evidence is hardly irrelevant to innocence. Cf. Stone v. Powell [428] U.S. [465] .... Indeed, an affirmative answer to this question means not merely that a defendant might have been, but that he was in fact improperly convicted. ${ }^{282}$

The utopian possibilities inherent in the guilt/innocence orientation thus center on the evidence and its uses. The general principles which control admissibility, allocation of burdens, presumptions, and sufficiency of evidence could become increasingly subject to constitutionalization with the new approach. A suggestion such as that of Justice Stewart in Freeman v. Zahradnick may be pushed very far or limited to cases which closely approximate the "no evidence" standard of Thompson v. City of Louisville. ${ }^{283}$ At its outer limit, the suggested principle may create a federal constitutional right to a correct verdict. Of course, to recognize the outer bounds of a principle is not to endorse pushing it to such a limit. But it is the breadth of such utopian vistas which gives life to the constitutional dialogue.

There is now ample evidence that most of the Court recognizes guilt/innocence as an important constitutional value which informs the processes of articulation and enforcement of constitutional law related to criminal justice. But this evidence emerges primarily from opinions using the principle to narrow the scope of constitutional rights or from separate dissents and concurring opinions. The majority of the Court still seems to believe that a serious constitutional principle may be articulated without disturbing existing institutions and relations. It is not distrust for the states but a basic philosophical distinction between idea and matter which grounds the contrary presumption. Habeas corpus may not be the only way in which the gulf between the real and the ideal may be mediated. But whatever form of dialectic is chosen will have its own characteristic costs for and intrusions upon the status quo. The only way to achieve the simplicity of leaving our social reality undisturbed is to cease confronting it with the word. As ideas by which to measure reality shrink so will the

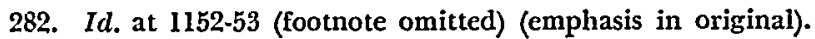

283. 362 U.S. 199 (1960). 
reality which they measure. Eventually Chief Justice Burger and Justice Rehnquist may achieve the quintessentially linear criminal process, devoid of redundancy, virtually costless, and without meaning.

The other Justices seem to want something more. But the majority refuses to recognize that what is persuasive and even moving in Stone v. Powell cannot coexist with Estelle v. Williams. In choosing to rest Stone upon an important idea, Justice Powell has provided the test for himself and his brethren. They will either build from it a body of law with different but no fewer or lesser implications for existing reality than that of the Warren Court; or they will make innocence and guilt a mockery-a euphemistic dressing for inaction in the face of injustice. The common antipathy to the substantive agenda of the Warren Court should not be permitted to obscure the gulf separating those professing ideals of guilt/innocence from those who would make of the criminal process an unforgiving trap for the defendant. The theory of guilt/innocence is ultimately irreconcilable with both an adjudicative structure based on combative individualism and with the refusal to reconsider possibly unjust results. But most important, the theory of guilt/innocence will never emerge as more than an apologetic slogan if is not subjected to the tempered elaboration of a dialectical federalism.

\section{Epilogue}

The attack on Fay v. Noia continues. After we completed this article the Court handed down Wainwright $v$. Sykes ${ }^{284}$-a case that, for the first time, openly confronts and limits Fay by holding that a defendant who failed to comply with a state's contemporaneous objection rule must establish "cause" and "prejudice" to raise a coerced-confession claim in a federal habeas proceeding.

In Wainwright $v$. Sykes the defendant was convicted of third-degree murder by a Florida jury. At the time of his arrest, the defendant had been warned of his Miranda rights; he declined counsel and confessed to the shooting. At trial he failed to object to the admission of his inculpatory statements, thus waiving the claim under the Florida Rules of Criminal Procedure. The defendant later asserted in state and federal habeas that he had been intoxicated at the time of the Miranda warnings and did not understand them; thus, he claimed, the confession was involuntary and should not have been admitted at trial. ${ }^{285}$

284. 45 U.S.X.W. 4807 (U.S. June 23, 1977).

285. Id. at $4808-09$. 
Justice Rehnquist wrote for the majority in Wainwright $v$. Skyes and reversed the Fifth Circuit's holding that the defendant was due relief because he had not deliberately bypassed the state procedure for testing the voluntariness of the confession. The Court decided to extend the rule of Francis $v$. Henderson to all claims not timely raised during a trial by a counseled defendant. Defendant would have to show "cause" for and "prejudice" from the procedural default. While Francis, Stone, and Estelle v. Williams essentially ignored Fay v. Noia, Wainwright v. Sykes is explicit in its retreat from Fay:

To the extent that the dicta of Fay v. Noia may be thought to have laid down an all-inclusive rule rendering state timely objection rules ineffective to bar review of underlying federal claims in federal habeas proceedings-absent a "knowing waiver" or a "deliberate bypass" of the right to so object-its effect was limited by Francis ....

... We leave open for resolution in future decisions the precise definition of the "cause" and "prejudice" standard, and note here only that it is narrower than the standard set forth in dicta in Fay v. Noia .... It is the sweeping language of [Fay], going far beyond the facts of the case eliciting it, which we today reject. ${ }^{286}$

Justice Rehnquist defended the extension of Francis in terms of respect for state rules, finality, and prevention of "sand bagging by defense counsel." He wrote that the "cause" and "prejudice" requirements would also adequately protect against miscarriages of justice. ${ }^{287}$

Wainwright $v$. Sykes obviously demonstrates the Court's continuing disenchantment with post-conviction attacks in federal district courts. But the concurring opinions indicate that the Court has not yet settled on its approach to the criminal law. Chief Justice Burger's opinion was true to the waiver theory. He stressed the role of counsel at trial and the inability of the defendant adequately to direct his own defense or knowingly and intelligently approve his counsel's trial tactics. ${ }^{288}$ Justice White's opinion, concurring in the judgment only, nodded towards the guilt/innocence theory by stating that the defendant should not have "shifted to him the burden of proving specific prejudice"; he felt that a "harmless error rule provides ample protection to the State's interest." 2 s9 White would also apparently keep

286. Id. at 4811-12 (footnote omitted).

287. Id. at 4812 .

288. Id, at 4813 (Burger, C.J., concurring).

289. Id. at 4814 (White, J., concurring in the judgment). 
Fay's deliberate bypass test, but would interpret it to require the defendant, in a habeas proceeding, to justify a failure to object if his counsel knew of the time limit. 290

Perhaps most interesting is the dissenting opinion of Justice Brennan, joined by Justice Marshall. Justice Brennan's dissent is strikingly different from his angry and wide-ranging opinions in Stone, Francis and Estelle v. Williams. He is methodical and scholarly in his defense of Fay and his attack on the majority opinion. One senses the end of an era in Brennan's words. His wish in Francis that he not be subsequently told that Francis had overruled Fay went unfulfilled.

But it appears that Brennan, rather than bemoaning the loss of Fay, is ready to take the Court on its own terms and to force the new majority to consistent application of its principles. He recognized the guilt/innocence theory, insisting that if the "guilt-related" trail of Stone "is to be followed, it would be quite unthinkable that an unintentional procedural default should be allowed to stand in the way of vindication of constitutional rights bearing upon the guilt or innocence of a defendant." $291 \mathrm{He}$ also criticized the waiver theory, asserting that the major reasons for failure to make a timely objection are simple attorney mistake, ignorance or carelessness. ${ }^{202}$ Such failures are unfairly visited upon a defendant since they "lie outside the power of the habeas petitioner to prevent or deter and for which, under no view of morality or ethics, can [he] be held responsible." ${ }_{293}$ Justice Brennan's solution is closer scrutiny of lawyers' actions by "conscientious and fair-minded federal and state courts." 204

Justice Brennan, then, is aware that while the values underlying Fay may have been transformed, the redundancy that it created needs to survive. Until Wainwright v. Sykes, Justice Brennan had criticized the Court for betraying the values of the Warren Court. Now, sadly enough, he has been forced to mark the Burger Court as a betrayer of its own values.

290. Id.

291. Id. at 4818 (Brennan, J., dissenting).

292. Id at at 4819 .

293. Id.

294. Id. at 4820 . 